\title{
INHIBITION OF HUMAN ACETYL- AND BUTYRYLCHOLINESTERASE BY NOVEL CARBAMATES OF (-)- AND (+)-TETRAHYDROFUROBENZOFURAN AND METHANOBENZODIOXEPINE
}

\author{
Weiming Luo ${ }^{1, \#}$, Qian-sheng Yu1,\#, Santosh S. Kulkarni ${ }^{2}$, Damon A. Parrish ${ }^{3}$, Harold W. \\ Holloway ${ }^{1}$, David Tweedie ${ }^{1}$, Avigdor Shafferman ${ }^{4}$, Debomoy K. Lahiri ${ }^{5}$, Arnold Brossi ${ }^{6}$, and \\ Nigel H. Greig ${ }^{1, *}$ \\ 1 Drug Design \& Development Section, Laboratory of Neurosciences, Gerontology Research Center, National \\ Institute on Aging, National Institutes of Health, 5600 Nathan Shock Dr., Baltimore, Maryland 21224, USA. \\ 2Medicinal Chemistry Section, Intramural Research Program, National Institute on Drug Abuse, National \\ Institutes of Health, 5500 Nathan shock Dr., Baltimore, MD 21224, USA. \\ 3Laboratory for the Structure of Matter, Department of the Navy, Naval Research Laboratory, Washington, \\ D.C. 20375, USA. \\ 4Department of Biochemistry and Molecular Genetics, Israel Institute for Biological Research, Ness-Ziona, \\ 74100 Israel. \\ 5Psychiatric Institute, Indiana University School of Medicine, Indianapolis, IN 46202, USA \\ 6School of Pharmacy, University of North Carolina at Chapel Hill, North Carolina 27599, USA
}

\section{Abstract}

A new enantiomeric synthesis utilizing classical resolution provided two novel series of optically active inhibitors of cholinesterase: (-)- and (+)- O-carbamoyl phenols of tetrahydrofurobenzofuran and methanobenzodioxepine. An additional two series of (-)- and (+)-O-carbamoyl phenols of pyrroloindole and furoindole were obtained by known procedures, and their anticholinesterase actions were similarly quantified against freshly prepared human acetyl- (AChE) and butyrylcholinesterase (BChE). Both enantiomeric forms of each series demonstrated potent cholinesterase inhibitory activity (with $\mathrm{IC}_{50}$ values as low as $10 \mathrm{nM}$ for $\mathrm{AChE}$ and $3 \mathrm{nM}$ for $\mathrm{BChE}$ ), with the exception of the (+)-O-carbamoyl phenols of pyrroloindole that lacked activity $\left(\mathrm{IC}_{50}\right.$ values $>1 \mu \mathrm{M}$ ). Based on the biological data of these four series, a SAR analysis was provided by molecular volume calculations. In addition, a probable transition state model was established according to the known X-ray structure of a transition state complex of Torpedo californica AChE-m-

(N,N,N,trimethylammonio)-2,2,2-trifluoroacetophenone (TcAChE-TMTFA). This model proved valuable in explaining the enantio-selectivity and enzyme subtype selectivity of each series. These carbamates are more or similarly potent to anticholinesterases in current clinical use; providing not only inhibitors of potential clinical relevance but also pharmacological tools to define drug-enzyme binding interactions within an enzyme crucial in the maintenance of cognition and numerous systemic physiological functions in health, aging and disease.

\footnotetext{
*To whom correspondence should be addressed: Phone: 410-558-8278; Fax: 410-558-8323, E-Mail: Greign@ grc.nia.nih.gov.

\#Weiming Luo and Qian-sheng Yu made equal contributions to this research and are equal first authors.
} 


\section{INTRODUCTION}

Dementia of the Alzheimer's type afflicts some 4.5 million Americans and some 18 million people worldwide. Based on the 'cholinergic hypothesis' of memory, the depletion of its neurotransmitter, acetylcholine ( $\mathrm{ACh}$ ), and loss of associated synapses during the progression of Alzheimer's disease (AD), 1,2 cholinesterase inhibitors (ChEIs) have been synthesized and developed to clinical practice to ameliorate the associated cognitive symptoms. ${ }^{3}$ This is achieved by reducing the rate of hydrolysis of $\mathrm{ACh}$ in brain and thereby augmenting its cholinergic activity. Although ChEIs and the recently FDA approved drug, memantine, are the only ones to have consistently induced improvements in cognitive function in mild to moderate $\mathrm{AD},{ }^{4}$ such improvements are, unfortunately, generally modest. Indeed, recent clinical trials have triggered debate as to the relevance of the benefit of this drug class. ${ }^{5,6}$ Such concern has prompted two avenues of research. One to develop a new generation of ChEIs with activity beyond the modest symptomatic one associated with initial agents, and another to optimize current agents based on a greater understanding of enzyme/inhibitor interactions. Our research focus has been to undertake both, simultaneously.

A classical ChEI, used to elucidate the original nature of chemical transmission of nerve action and the cholinergic system (Sir Henry Dale and Professor Otto Loewi, Nobel Prize 1936), is the natural product, (-)-physostigmine (15a). An alkaloid isolated from the seeds of the Calabar bean, Physostigma venenosum, ${ }^{7-9}(-)$-physostigmine (15a) has provided a template in the development of several AD drugs, including rivastigmine (Novartis, Basel, Switzerland), phenserine (National Institute on Aging, Baltimore, MD, and Axonyx, New York, NY), eptylstigmine (Mediolanum, Milan, Italy) and the parent compound, itself, in a slow-release formulation (Synapton, Forrest laboratories, St Louis, MO). ${ }^{3,10,11}$ Extensive structureactivity relationships of this class of ChEIs indicates that (i) all derivatives of physostigmine with anticholinesterase activity are levorotary, with a $3 \mathrm{a}-S$ configuration in their pyrroloindole tricyclic ring system, and, (ii) selectivity between the two cholinesterase forms, acetyl- (AChE: EC3.1.1.7) and butyrylcholinesterase (BChE: EC 3.1.1.8), is primarily correlated with the structure of the $\mathrm{N}$-substituted moiety of the carbamoyl side chain. ${ }^{10-12}$

An exception to the enantiomeric selectivity of physostigmine derivatives is the $N^{l}$-nor series of derivatives. ${ }^{13,14}$ (-)-Physovenine (20a), a congeneric alkaloid of physostigmine, ${ }^{9,10}$ also lacks enantiomeric selectivity. ${ }^{10,15,16}$ The (+)-isomers of these two series of compounds, interestingly, have unexplainable anticholinesterase activity. ${ }^{13-16}$ In our continuing effort to design new and improved ChEIs, we recently successfully synthesized two novel series of bioactive racemic carbamates with the tricyclic skeletons, furobenzofuran and methanobenzodioxepine. ${ }^{17}$ Herein, we describe the synthesis and activity of their optically pure enantiomers with the dual purpose of (i) developing new AD drug candidates and (ii) utilizing them as tools to elucidate the molecular interactions required by the tricyclic skeleton of this important class of $\mathrm{ChEI}$ to achieve enantio-selectivity within $\mathrm{AChE}$ and $\mathrm{BChE}$.

\section{RESULTS}

\section{Chemistry}

The starting material, 5-hydroxy-3-methyl-3-methoxycarbonylmethylene-benzofuran-2-one (1), was produced from C3-alkylation of the condensation product of 1,4-cyclohexandione and pyruvic acid, according to a previously reported procedure. ${ }^{17}$ First, compound $\mathbf{1}$ was reacted with (-)-menthyl chloroformate to provide a mixture of the stereoisomers of $(3 S)$ and $(3 R)$ menthylcarbonates of 5-hydroxy-3-methyl-3-methylacetate-benzofuran-2-one $\mathbf{2}$ and $\mathbf{3}$ (Scheme 1). 
Since it proved difficult to isolate stereoisomer $\mathbf{2}$ and $\mathbf{3}$ with chromatography, we separated them by repeated crystallization. This was performed from hexane, at first, and then from ethanol to eventually yield two separate crystals with different crystalline forms: needle (2) and flaky (3) (Experimental Section).

The absolute configuration of the C-3 position was determined based on the known configurations of C-19, C-21 and C-24 from compound 3 by X-ray crystallography. Figure 1 shows that compound $\mathbf{3}$ has a $R$ configuration at its 3-position. As a consequence, compound 2 should possess a $S$ configuration at its 3-position. The use of chiral HPLC to measure the optical purity of compounds $\mathbf{2}$ and $\mathbf{3}$ proved unsuccessful. The hydrolysis of stereoisomer $\mathbf{2}$ and 3 provided (-)-enantiomer $4,[\alpha]_{\mathrm{D}}{ }^{26}-2.6^{\circ}\left(\mathrm{C}=0.62, \mathrm{CHCl}_{3}\right)$, and (+)-enantiomer $\mathbf{5}$, $[\alpha]_{\mathrm{D}}^{27}+2.2^{\circ}\left(\mathrm{C}=0.45, \mathrm{CHCl}_{3}\right)$ (Scheme 1), respectively. The enantiomeric excesses value (ee $\%$ ) of each was measured by chiral HPLC analysis and reported in the Experimental Section (Figure 2). Compounds $\mathbf{4}$ and $\mathbf{5}$ were, for practical purposes, optically pure. In the process of reduction, the stereochemistry at the 3 -position of compounds $\mathbf{2}$ and $\mathbf{3}$ was unchanged. Hence, $\mathbf{2}$ gave $\mathbf{6 a}$ ( $3 \mathrm{a} S$-configuration) and $7 \mathbf{a}(5 S$-configuration); whereas, 3 gave $\mathbf{6 b}(3 \mathrm{a} R$ configuration) and $\mathbf{7 b}$ ( $5 R$-configuration). The probable mechanism underpinning this reductive cyclization has recently been published. ${ }^{17,} 18$ In our recent prior research, we reported that the reductive cyclization of ( \pm )-5-hydroxy-3-methyl-3-methylacetatebenzofuran-2-one by $\mathrm{LiAlH}_{4}$ gave tetrahydrofurobenzofuran and methanobenzodioxipene in a yield of $10 \% .{ }^{17}$ In the present report, the reductive lithium-aluminum complexes of compound 2 and 3 were acidified by $1 \mathrm{M} \mathrm{HCl}$ in anhydrous $\mathrm{Et}_{2} \mathrm{O}$, instead of oxalic acid, to elevate the yield to approximately $30 \%$ (Scheme 2).

Phenols $6 \mathbf{a}$ and $7 \mathbf{a}$, as well as $6 \mathbf{b}$ and $7 \mathbf{b}$ were reacted with different isocyanates to give 6 pairs of corresponding carbamates: 8a and 11a, 9a and 12a, 10a and 13a, as well as $8 \mathbf{b}$ and 11b, $9 \mathrm{~b}$ and $12 \mathrm{~b}, 10 \mathrm{~b}$ and $13 \mathrm{~b}$, respectively. Thereafter, each of these pairs of compounds was separated by preparative TLC, utilizing a procedure reported previously. ${ }^{17}$

The syntheses of carbamates of the physostigmine and physovenine series of analogues are shown in Scheme 3. Compounds 15a and $\mathbf{b}, 17 \mathbf{a}, 18 \mathbf{a}, 20 \mathbf{a}$ and $\mathbf{b}, 22 \mathbf{a}$ and 23a are known compounds. ${ }^{15,16}$ Compounds 16 a and 21 a were synthesized from compounds $14 a$ and 19a, which were obtained from natural physostigmine according to a known procedure. ${ }^{17}$

Compounds 17b, 18b, 22b and 23b were synthesized from (+)-3a $(R)$-eseroline $(\mathbf{1 4 b})$ and $(+)-3 \mathrm{a}(R)$-physovenol $(\mathbf{1 9 b})$. These phenols, $(\mathbf{1 4 b})$ and $(\mathbf{1 9 b})$, were obtained by asymmetric syntheses starting from $\mathrm{N}$-methylphenetidine. ${ }^{14}$

\section{X-ray Crystallography}

The results of the $\mathrm{X}$-ray studies of compound $\mathbf{3}$ are illustrated in Figure 1. The chirality of the asymmetric center are as follows: $\mathrm{C} 3-R, \mathrm{C} 19-R, \mathrm{C} 21-R$ and $\mathrm{C} 24-S$. The six-membered ring of the menthyl moiety has a chair conformation; in contrast, the benzofuran system is flat.

\section{Biological Evaluation}

Table 1 shows the anticholinesterase activity of enantiomers 8-13, 15-18 and 20-23 against freshly prepared human $\mathrm{AChE}$ and $\mathrm{BChE}$, derived from erythrocytes and plasma, respectively. The concentration of compound required to inhibit 50\% enzyme activity $\left(\mathrm{IC}_{50}\right.$ value) was quantified by a modified Ellman technique, ${ }^{13-17,19-21}$ and values for $R$-configuration versus $S$-configuration are represented by the symbol $R / S$. A smaller $\mathrm{IC}_{50}$ is associated with a lower $K \mathrm{i}$ value and a higher affinity of inhibitor-enzyme binding. ${ }^{22-24} \mathrm{~A} R / S$ value of 1 is indicative of similar inhibitory activity for the $R$ - and $S$-configurations. For a $R / S$ value $>1$, the compound with a $R$-configuration has a lower potency than its enantiomer. 
With the sole exception of the compound pair, $17 \mathbf{a}$ and $\mathbf{1 7} \mathbf{b}$, that possessed low and approximately similar BChE inhibitory activity $(R / S=0.6)$, all compounds with a $S$ configuration proved to be more potent than their corresponding enantiomer $(R / S>1)$. This was most evident in the physostigmine series, where AChE inhibitory activity was achieved with a $R / S$ value $\geq 353$ and $\mathrm{BChE}$ inhibitory action was achieved with a $R / S$ value $\geq 102$. Hence, in the physostigmine series, carbamates of (+)-physostigmine $(\mathbf{1 5 b}, \mathbf{1 7 b}, \mathbf{1 8 b})$ possess minimal cholinergic activity, quite the opposite of their potent (-)-enantiomers.

In complete contrast with the physostigmine series, both enantiomers of the novel tetrahydrofurobenzofuran (8a and $\mathbf{b}, \mathbf{9 a}$ and $\mathbf{b}, \mathbf{1 0 a}$ and $\mathbf{b})$ and dihydrobenzodioxepine (11a and $\mathbf{b}, \mathbf{1 2} \mathbf{a}$ and $\mathbf{b}, 13 \mathbf{a}$ and $\mathbf{b}$ ) series possessed potent anticholinesterase action for $\mathrm{AChE}, \mathrm{BChE}$ or both, with $R / S$ values of $\leq 9.3$. This activity is in accord with the congener, physosvenine carbamates (20a and $\mathbf{b}, 21 \mathbf{a}$ and $\mathbf{b}, 22 \mathbf{a}$ and $\mathbf{b}, 23 \mathbf{a}$ and $\mathbf{b})$ that are similarly active in both enantiomeric forms with a preference for the $S$-configuration. As described, N-demethylation of physostigmine (15a) minimizes the enantio-selectivity of this series, ${ }^{14}$ which suggests that the $\mathrm{N}^{1}$-substitution of the tricyclic ring is a key determinant regarding enantio-selectivity. Additionally, the development of members of the tetrahydrofurobenzofuran and dihydrobenzodioxepine series to clinical development could be undertaken with either the potent $S$ - (-)-enantiomers or the racemates, whose synthesis would be far easier and cheaper (avoiding optical resolution) and whose anticholinesterase activity is almost equal. A comparison of Table 1 and Table 2, the latter defining the anticholinesterase activity of agents of current and recent clinical interest against enzyme drawn from the same individual and analyzed similarly, suggests that compounds 9a, 12a and 10a, 13a possess sufficient potency and selectivity for $\mathrm{AChE}$ and $\mathrm{BChE}$, respectively, to be of clinical interest.

In each of the four series of compounds detailed in Table 1, the differential selectivity for AChE or $\mathrm{BChE}$ is determined by the structure of $\mathrm{N}$-substituted moiety of the carbamate. Specifically, the $\mathrm{N}$-methyl carbamates provide minimal enzyme subtype selectivity. The $\mathrm{N}$-ethyl carbamates have a moderate $\mathrm{BChE}$ preference. The $\mathrm{N}-2$ '-methylphenylcarbamates have high $\mathrm{AChE}$ selectivity and $\mathrm{N}-4$ '-isopropylphenylcarbamates reverse this and demonstrate a high $\mathrm{BChE}$ preference. Of particular note, the $\mathrm{AChE}$ and $\mathrm{BChE}$ selectivities of the novel tetrahydrofurobenzofuran and dihydrobenzodioxepine series are amongst the greatest found of all ChEIs yet synthesized on the tricyclic backbone of physostigmine.

\section{DISCUSSION}

\section{Molecular comparison by volume calculations}

As all of the described carbamates possess close structural similarity as well as a similar inhibitory mechanism, we can initially compare them by means of superimposition to further elucidate the basis of their enantio-selectivity. This was undertaken for the four AChE potent inhibitors with $S$-configuration carbamates $(\mathbf{9 a}, 12 \mathbf{a}, 17 \mathbf{a}$ and 22a) by generating a 'molecular volume map' of each molecule that corresponds to their van der Waals surface. ${ }^{25,26}$

As illustrated in Figure 3, for each compound, the relative positions of their two phenyl moieties, on either side of the carbonyl group in their optimized conformation, were almost identical - closely overlaying one another. These four compounds could be closely superimposed, except for disparity in their tricyclic systems. The combined molecular volume map of compounds 9a, 12a, 17a and 22a provides an 'enzyme - excluded map' (green area in Figure 3), within which all active compounds should fit. The molecular volume of the $R$-2'methylphenyl carbamates, $\mathbf{9 b}, \mathbf{1 2 b}, \mathbf{1 7} \mathbf{b}$ and $\mathbf{2 2 b}$, minus the enzyme - excluded volume provides an 'estimate volume' that represents the additional volume generated by that of each $R$-isomer (yellow meshed area within Figure 3). 
As shown in Table 3 , the lowest estimate extra volume of compound $9 \mathbf{b}\left(7.1 \AA^{3}\right)$ corresponds to the lowest enantio-selectivity $(R / S=1.8)$. The highest estimate extra volume $\left(24.8 \AA^{3}\right)$ of compound $\mathbf{1 7 b}$ corresponds to the highest enantio-selectivity $(R / S=551)$. Specifically, the larger estimate extra volume of compound $\mathbf{1 7 b}$ (yellow meshed area in Figure 3 ) likely seriously hinders the approach to and hence binding between the inhibitor and enzyme. Molecular modeling studies were undertaken to aid elucidate how this additional estimate extra volume hinders binding.

\section{Molecular model of the transition state}

The wide structural diversity of available ChEIs suggests that unlike types of inhibitors bind with AChE in different ways via disparate yet specific interactions between compound and enzyme. ${ }^{27-29}$ Most anticholinesterases, such as those in Table 2 as well as the potent nonclinical tacrine-based triazoles and other hybrids, are cationic at physiological $\mathrm{pH}$; whereas some, including those of the present study and arisugacin, are not. ${ }^{30-32}$ Human cholinesterases are large complex molecules composed of catalytic subunits that can clearly accommodate a variety of specific binding interactions associated with these diverse inhibitors. They contain up to 583 amino acids, a Mr of 70-80 kDa, and are variably glycosylated. 29,33

Three-dimensional analyses of AChE and BChE, based on x-ray crystallography, have provided structural information regarding the positioning of the catalytically important amino acid residues within these proteins. ${ }^{34-41}$ In synopsis, three major binding domains have been described within AChE and two within BChE in an internalized, primarily hydrophobic gorge of some $20 \AA$ length, but as narrow as $0.5 \AA$ wide. Deepest within this gorge is a catalytic 'acyl' binding domain, which hydrolyses choline esters through electron transfer within a catalytic triad, termed a 'charge relay system. The triad includes a $S_{200}$, the imidazole group of a $\mathrm{His}_{440}$, and the carboxylic acid moiety of a Glu 327 (TcAChE numbering). A 'choline' binding domain resides midway along the gorge, and a 'peripheral' anionic site exists at the gorge mouth for $\mathrm{AChE}$ but not $\mathrm{BChE},{ }^{30-41}$ and this latter site may be involved in the complexing of AChE with amyloid- $\beta$ peptide in the Alzheimer brain. ${ }^{42}$ Notably, the neurotoxicity associated with $\mathrm{A} \beta-\mathrm{AChE}$ complexes has been shown to be greater than that induced by the $\mathrm{A} \beta$ peptide alone in both cell culture and animal experiments. 39

On the basis of calculations and electro-optical measurements, it has been suggested that electrostatic charges associated with seven negatively charged amino acids residues close to the entrance of the gorge trap and steer charged ligands into its mouth. ${ }^{43,44}$ In the case of $\mathrm{ACh}$, the quaternary choline moiety interacts with $\operatorname{Trp}_{84}$ of $T c \mathrm{AChE}$ and, to a lesser extent, with $\mathrm{Phe}_{330}$ within the choline binding domain. This orientates the compound to allow the approach and nucleophilic attack of the catalytic triad on its carbonyl group. A quaternary transition state between Ser $_{200}$ and ACh momentarily exists that then rapidly collapses into an acylated-enzyme intermediate and released choline. Thereafter, prompt hydrolysis of the acetylester reactivates the enzyme to allow efficient cleavage of as many as $10^{4} \mathrm{ACh}$ molecules per second. 37,38 (-)-Physostigmine (15a) and analogues interact similarly with the same two binding domains. However, nucleophilic attack of its carbonyl moiety results in a transient (-)physostigmine-AChE intermediate, in a tetrahedral conformation, that then swiftly collapses to a carbamylated drug-enzyme complex that is dramatically more stable than the acetyl enzyme one associated with ACh; enzyme inhibition occurs consequent to the slow rate of enzyme decarbamylation. The inhibition process, hence, involves AChE-catalyzed hydrolyses of inhibitors. ${ }^{37,38}$ In such a chemical reaction, the highest energy transition state controls the overall rate of the reaction. A catalytic enzyme can lower this energy barrier by specific interaction with the inhibitor in the transition state $(\mathbf{2 4}-\mathbf{2 5}) .45$ (Scheme 4). As shown in Table 1 , each of the eight different carbamates with a same N-substituted side chain (e.g., 8 a and b, $11 \mathbf{a}$ and b, $16 \mathbf{a}$ and $\mathbf{b , 2 1} \mathbf{a}$ and $\mathbf{b})$ should generate identical carbamylated enzyme structures 
after their reaction with either $\mathrm{AChE}$ or $\mathrm{BChE}$. Hence their different $\mathrm{IC}_{50}$ values should be related to their affinities and rates of carbamylation, and not to decarbamylation - which would impact the time-dependence of the inhibition associated with each. As a consequence we can focus on carbamylation due to the short time frame of our biological studies.

A better insight into the molecular interactions of the enzyme and inhibitor can be obtained at the transition state. Whereas it is not currently possible to produce a crystal structure of an enzyme complexed with its substrate in the transition state, due to the short transition state lifetime versus the time required for X-ray data collection, one can exploit the high affinity of transition state analogues. In this regard, the analogue, $\mathrm{m}-(N, N, N$-trimethylammonio $)-2,2,2-$ trifluoroacetophenone (TMTFA), possessing a low $K \mathrm{i}$ (15 fM) for inhibition of TcAChE, ${ }^{46}$ was utilized to aid model the interaction of our compounds within the active site of AChE.

Prior investigation of the X-ray crystallographic structure of $T c \mathrm{AChE}$ complexed with the known physostigmine analogue, MF268 (8-(cis-2,6-dimethylmorpholino) octylcarbamoyleseroline), demonstrated the presence of a covalent bond between the carbonyl carbon and $\gamma-\mathrm{O}$ of $\mathrm{Ser}_{200}$, and that the N-substituted side chain of the carbamoyl moiety is located inside the acyl-binding pocket and extends to the rim of the active site gorge. ${ }^{47,48}$ The $\mathrm{X}$-ray crystallographic transition state analogue structure of $T c$ AChE-TMTFA (code 1AMN) was obtained from the RCSB protein databank. After extraction of TMTFA, the (-)-(3aS)$\mathrm{N}-2$ '-methylphenylcarbamoyl phenol of furobenzofuran (9a) was docked, in accord with knowledge gained from the binding of MF268. ${ }^{47,48}$

As shown in Figure 4, six hydrogen bonds are apparent within the model (yellow lines): the $\mathrm{NH}$ of $\mathrm{Gly}_{118}$, Gly 119 and $\mathrm{Ala}_{201}$ with the oxygen of the ligand carbonyl, the $\gamma-\mathrm{O}$ of $\mathrm{Ser}_{200}$ with a single $\mathrm{H}$, the hydrogen with $\mathrm{N}$ of His 440 , and the $\mathrm{NH}$ of His 440 with the oxygen of $\mathrm{Glu}_{327}$. Together with the covalent bond of the $\gamma-\mathrm{O}$ of $\mathrm{Ser}_{200}$ with the $\mathrm{C}$ of the ligand's carbonyl group, the illustrated hydrogen bonds comprise an acylation site. This site is considered as a crucial part of the transition state. A transition state model was developed by (i) keeping the acylation site intact (by constraining the relative distances between the described atoms) and, (ii), minimizing the complex energy, after automatic adjustment of the conformation of the remaining complex.

This model resembles a 'beam balance'. The central supporting point is a covalent bond between the $\gamma-\mathrm{O}$ of $\operatorname{Ser}_{200}$ and the C of the ligand's carbonyl group. The $\pi-\pi$ interaction system between the N-phenyl group of carbamate (9a) and the phenyl group of $\mathrm{Phe}_{288}$ of the enzyme comprises one side of this balance. The $\pi-\pi$ or lipophilic $\left(\mathrm{C}-\mathrm{H}^{\prime} \pi\right)$ interaction system of the furobenzofuran moiety of compound $9 \mathrm{a}$ and the indole system of $\operatorname{Trp}_{84}$ of the enzyme forms the other side of the balance. Such $\mathrm{C}-\mathrm{H}^{\cdots}{ }^{\prime} \pi$ interactions have been observed in the x-ray crystal structure of other neutral molecules with $T c \mathrm{AChE} .{ }^{49}$ Any change on either side of this balance may adversely affect the formation of the transition state. Utilizing this model, we can revisit the basis of enantio-selectivity and enzyme subtype selectivity.

\section{Enantio-selectivity}

As shown by molecular volume calculations (Figure 3, Table 3), for all carbamates with a $R$ configuration, with the exception of the physostigmine series, their molecular volumes are not greatly different. This would support the lipophilic interaction between the tricyclic ring system of the ligands and the indole system of $\operatorname{Trp}_{84}$ of the enzyme. Hence, all of these compounds retain substantial anticholinesterase activity compared to their $S$-isomers.

The only exception involves $R$-configuration compounds having a $\mathrm{N}^{1}$-methyl group (the physostigmine series). The model predicts that the $\mathrm{N}^{1}$-methyl group will become inserted between the tricyclic ring system and the indole system of Trp84. The lipophilic interaction 
will consequently disappear, and a transition state between ligand and enzyme complex would not be readily formed without this lipophilic interaction. As a result, the (+)-physostigmine analogues $\mathbf{1 5 b}, \mathbf{1 7 b}$ and $\mathbf{1 8 b}$ would be predicted to possess a poor AChE and BChE inhibitory action, in accord with their measured poor ChEI activity.

\section{Enzyme subtype selectivity}

The acyl-binding pockets within $\mathrm{AChE}$ and $\mathrm{BChE}$ differ from one another in size and shape. The pockets can be differentiated on the basis of two amino acid residues located at the bottom of the acyl-loop. These residues are aromatic in AChE ( $\mathrm{Phe}_{288}$ and $\mathrm{Phe}_{290}$ ) but aliphatic in $\mathrm{BChE}\left(\mathrm{Leu}_{286}\right.$ and $\left.\mathrm{Val}_{288}\right) .33,35,37,38,46$ The latter pocket, hence, is slightly larger due to the smaller protruding side chains associated with Leu and Val. ${ }^{12}$.

Our previous studies have shown that the conformational energy barrier of the $\mathrm{N}$-phenyl group of compound 17a and its analogues, rotated around $\mathrm{Cl}^{\prime}-\mathrm{N}$ bond, is correlated to the $\mathrm{IC}_{50}$ of $\mathrm{AChE}$. A higher energy barrier is associated with a lower inhibitory activity (a larger $\mathrm{IC}_{50}$ ); although, inexplicably, the energy barrier is as low as $0-0.7 \mathrm{kcal} / \mathrm{mol} .21$

According to the described transition state model (Figure 4), the $\pi-\pi$ interaction system between the N-phenyl group of the carbamate (17a) and the phenyl group of Phe 288 of the enzyme comprises one side of this balance. Rotation of the N-phenyl group will decrease this $\pi-\pi$ interaction and directly influence the stability of the transition state; consequently lowering the affinity between ligand and enzyme. ${ }^{21}$

Utilizing the same model, we can now propose a basis for the cholinesterase subtype selectivity of the different carbamates moieties. (i) The small methyl group of N-methylcarbamates has almost no lipophilic interaction with residues of the acyl pocket, it thus has little influence on this balance and hence there is minimal subtype selectivity between AChE and BChE for Nmethyl carbamates of all series. (ii) The ethyl group of N-ethylcarbamates, likewise, has relatively meager, but, nevertheless, greater lipophilic interaction than $\mathrm{N}$-methylcarbamates. The direction of this interaction is more favorable to form a stable transition state within $\mathrm{BChE}$ than AChE. Hence, all of N-ethyl carbamates possess a moderate BChE selectivity. (iii) The phenyl group of N-phenylcarbamates provides a significant lipophilic interaction with the aromatic ring of $\mathrm{Phe}_{288}$. This interaction together with the lipophilic interaction between the tricyclic ring system and indol moiety of $\operatorname{Trp}_{84}$ provides a highly stable transition state. Thus, all $\mathrm{N}$-phenyl and $\mathrm{N}$-methylphenyl carbamates possess potent AChE activity. Within BChE, however, $\mathrm{Phe}_{288}$ is replaced by an amino acid with an aliphatic residue. A similar $\pi-\pi$ interaction cannot be formed and leads to an unfavorable stability in the transition state, and consequent weak $\mathrm{BChE}$ inhibitory activity. N-phenyl and $\mathrm{N}$-methylphenyl carbamates hence have high AChE selectivity. Finally, (iv) the 4'-isopropylphenyl moiety of N-4'isopropylphenyl carbamates cannot achieve a $\pi-\pi$ interaction within the acyl-binding pocket of AChE consequent to the bulk and hindering action of the isopropyl moiety. Within BChE, however, the lipophilic interaction of the isopropylphenyl group with residues of $\mathrm{BChE}$ in its larger acyl-binding pocket is favored (consequent to replacement of AChE Phe 288 and $\mathrm{Phe}_{290}$ by Val and Leu), which stabilizes the transition state. Thus all of the N-4'isopropylphenyl carbamate series have a potent and selective BChE inhibitory action.

In accord with this, one of the most potent and selective $\mathrm{BChE}$ inhibitors in the physostigmine series, (-)- $\mathrm{N}^{1}$-phenethylnorcymserine $(\mathbf{2 6})\left(\mathrm{IC}_{50}\right.$ : AChE $>30,000 \mathrm{nM}$, BChE 6.0 $01.0 \mathrm{nM}$, selectivity $>5000$-fold BChE) (Fig. 5), ${ }^{19}$ similarly can fit within the elongated acyl binding pocket associated with $\mathrm{BChE}$. However, as the $\mathrm{N}^{1}$-phenethyl moiety is directed outside the lipophilic interaction system, activity is not perturbed. Indeed, it is augmented, likely, as a consequence of hydrophobic interactions close to the gorge mouth. Interestingly, the elongated (-)-4'-benzoxyphenyl carbamate of physostigmine, 27 (Fig. 5), ${ }^{50}$ that lacks a hindered 4'- 
isopropyl group, can maintain the $\pi-\pi$ interaction associated with potent $\mathrm{AChE}$ binding, but make use of the larger acyl pocket associated with $\mathrm{BChE}$ to achieve $\mathrm{BChE}$ inhibitory potency $\left(\mathrm{IC}_{50}: \mathrm{AChE} 58 \pm 4 \mathrm{nM}, \mathrm{BChE} 7.0 \pm 1.0 \mathrm{nM}\right.$, selectivity 7-fold BChE). ${ }^{50}$

In synopsis, we report a new enantiomeric synthesis, through classical resolution, of two novel series of potent anticholinesterases: the O-carbamoyl phenols of furobenzofuran and benzodioxepine. These two series provide candidates to selectively inhibit either AChE or $\mathrm{BChE}$ and, additionally, include some that possess neurotrophic actions. ${ }^{17}$ Such actions may or may not be cholinergically mediated and provide this class of drugs actions beyond those that are classically considered to be only symptomatic. ${ }^{51,52}$ Carbamates of these novel series are sufficiently active to be of potential clinical interest, comparing favorably with the inhibitory action of approved and recent ChEIs (Table 2, Figure 6), and could be developed either as their potent $S$-enantiomers or as their synthetically cheaper racemates. In addition, their enzyme subtype selectivity compare favorably with the classical selective anticholinesterases, BW284c51 and iso-OMPA. Based on the described molecular volume calculations and known X-ray structure of a transition state complex of TcAChE-TMTFA, we have developed a beam balance-like transition state model of the $T c$ AChE-N-phenylcarbamate complex. Using this model, we can now propose a basis to account for the enantio-selectivity of physostigmine and its congeners.

\section{Experimental Section}

\section{Chemistry}

Melting points (uncorrected) were measured with a Fisher-Johns apparatus; ${ }^{1} \mathrm{H}$ NMR and ${ }^{13} \mathrm{C}$ NMR were recorded on a Bruker (Bellevica, MA) AC-300 spectrometer; MS (m/z) were recorded on a Hewlett-Packard 5973 GC-MS (CI); HRMS were performed by the UCR Mass Spectrometry Facility, Department of Chemistry, University of California; Optical rotations were measured by JASCO, Model DIP-370 (Japan, Spectroscopic Co., LTD.); Elemental analyses were performed by Atlantic Microlab, Inc.; The ee\% value of optically active compounds was determined by HPLC analyses using a HP1100 instrument and a chiral column (ChiraDex® $5 \mu \mathrm{m}$ ) (Agilent Technology), mobile phase $\mathrm{MeOH} / \mathrm{H}_{2} \mathrm{O}=45 / 55$, elution rate 0.5 $\mathrm{ml} / \mathrm{min}$., UVD $254 \mathrm{~nm}$ - all at room temperature. All reactions involving non-aqueous solutions were performed under an inert atmosphere.

(3S) And (3R)-Menthyl carbonates of 5-hydroxy-3-methyl-3-methylacetate-benzofuran-2-one (2) and (3)

Under a nitrogen atmosphere, a solution of 5-hydroxy-3-methyl-3methoxycarbonylmethylenebenzofuran-2-one (1) $(116 \mathrm{mg}, 0.491 \mathrm{mmol})$ in $0.06 \mathrm{~mL}$ of triethylamine and $1.5 \mathrm{~mL}$ of benzene was dropwise added into (-)-menthyl chloroformate $(118 \mathrm{mg}, 0.539 \mathrm{mmol})$ at room temperature. The mixture was stirred for 1.5 hours at the same temperature. The crude product was subjected to chromatography on silica gel (EtOAc/ Hexane $=1 / 3)$ to give $156.5 \mathrm{mg}$ of white crystalline product, yield $76.2 \%:{ }^{1} \mathrm{H}-\mathrm{NMR}\left(\mathrm{CDCl}_{3}\right) \delta$ 7.20-7.02 (m, 3H, Ar-H), 4.68-4.52 (m, 1H, CH-OC=O), $3.53\left(\mathrm{~s}, 3 \mathrm{H}, \mathrm{CH}_{3} \mathrm{O}\right), 3.10,2.96(\mathrm{AB}$, $\left.\mathrm{J}_{\text {gem }}=17.6 \mathrm{~Hz}, 2 \mathrm{H}, \mathrm{C} 3-\mathrm{CH}_{2} \mathrm{COO}\right), 2.21-2.11\left(\mathrm{~m}, 1 \mathrm{H}, \mathrm{CH}-{ }^{\mathrm{i}} \mathrm{Pr}\right), 2.10-1.98(\mathrm{~m}, 1 \mathrm{H}, \mathrm{CHMe})$, 1.80-1.65 (m, $\left.1 \mathrm{H}, \mathrm{CHMe}_{2}\right), 1.51$ (s, 3H, C3- $\left.\mathrm{CH}_{3}\right), 1.59-1.41\left(\mathrm{~m}, 2 \mathrm{H}, \mathrm{CH}_{2} \mathrm{COC}=\mathrm{O}\right), 1.26-0.80$ (m, $4 \mathrm{H}, \mathrm{CH}_{2} \mathrm{CH}_{2}$ ), 0.97 (d, 6H, $\mathrm{CH}_{3} \mathrm{CCH}_{3}$ ) and 0.85 (d, 3H, $\left.\mathrm{CH}_{3} \mathrm{CCCOC}=\mathrm{O}\right)$ ppm; CI-MS $\left(\mathrm{CH}_{4}\right), \mathrm{m} / \mathrm{z}: 419\left(\mathrm{MH}^{+}\right), 418,417,371,237,181,153$ and 109; HR-MS m/z: Calcd for $\mathrm{C}_{23} \mathrm{H}_{34} \mathrm{NO}_{7}\left(\mathrm{MNH}_{4}{ }^{+}\right)$: 436.2335; Found: 436.2326 . The above white crystal product was, thereafter, recrystallized from both hexane and ethanol, separately, several times, until the optical rotations and melting points of the two different isolated crystalline forms did not change. One, a needle crystalline form, was product 2: m.p. $106.8-107.4^{\circ} \mathrm{C} ;[\alpha]_{\mathrm{D}}{ }^{25}-60.8^{\circ}$ 
( $\left.\mathrm{c}=0.53, \mathrm{CHCl}_{3}\right)$. Anal. $\left(\mathrm{C}_{23} \mathrm{H}_{30} \mathrm{O}_{7}\right) \mathrm{C}, \mathrm{H}$. The other, a flaky crystalline form, was product 3 : m.p. $148.0-148.8^{\circ} \mathrm{C} ;[\alpha]_{\mathrm{D}}^{26}-19.7^{\circ}\left(\mathrm{c}=0.74, \mathrm{CHCl}_{3}\right)$. Anal. $\left(\mathrm{C}_{23} \mathrm{H}_{30} \mathrm{O}_{7}\right) \mathrm{C}, \mathrm{H}$.

\section{(-)-(3S)-5-Hydroxy-3-methyl-3-methylacetate-benzofuran-2-one (4)}

Under a nitrogen atmosphere, a mixture of reactant $2(0.493 \mathrm{~g}, 1.178 \mathrm{mmol})$ and sodium hydroxide $(0.2 \mathrm{~g}, 5.0 \mathrm{mmol})$ in $18 \mathrm{~mL}$ of methanol was stirred for 1.5 hours at room temperature. It was then neutralized with $1 \mathrm{~N} \mathrm{HCl}$. After removing solvent, the residue was chromatographed on silica gel $\left(\mathrm{CH}_{2} \mathrm{Cl}_{2} / \mathrm{MeOH}=10 / 1\right)$ to give $168.2 \mathrm{mg}$ of product 4, yield $60.4 \%$ : m.p. 157.0 $159.0^{\circ} \mathrm{C} ;[\alpha]_{\mathrm{D}}{ }^{26}-2.6^{\circ}\left(\mathrm{c}=0.62, \mathrm{CHCl}_{3}\right)$; ee\% $=100 \%$ (HPLC); ${ }^{1} \mathrm{H}-\mathrm{NMR}\left(\mathrm{CDCl}_{3}\right) \delta 6.92-6.61$ $(\mathrm{m}, 3 \mathrm{H}, \mathrm{Ar}-\mathrm{H}), 5.07(\mathrm{~s}, 1 \mathrm{H}, \mathrm{OH}), 3.44\left(\mathrm{~s}, 3 \mathrm{H}, \mathrm{OCH}_{3}\right), 3.02,2.84\left(\mathrm{AB}, \mathrm{J}_{\text {gem }}=18.0 \mathrm{~Hz}, 2 \mathrm{H}, \mathrm{C} 3-\right.$ $\left.\mathrm{CH}_{2} \mathrm{C}=\mathrm{O}\right)$ and 1.41(s, 3H, C3-CH 3$)$ ppm; CI-MS $\left(\mathrm{CH}_{4}\right), \mathrm{m} / \mathrm{z}: 237\left(\mathrm{MH}^{+}\right), 205,177$ and 163.

\section{(+)-(3R)-5-Hydroxy-3-methyl-3-methylacetate-benzofuran-2-one (5)}

Compound 5 was prepared as described above, yield $66.0 \%$ : m.p. $156.0-158.6{ }^{\circ} \mathrm{C} ;[\alpha]_{\mathrm{D}}{ }^{27}+2.2$ ${ }^{\circ}\left(\mathrm{c}=0.45, \mathrm{CHCl}_{3}\right)$; ee $\%=100 \%$. The ${ }^{1} \mathrm{HNMR}$ and CI-MS $\left(\mathrm{CH}_{4}\right)$ are the same as that of compound 4.

(3aS)-5-Hydroxy-3a-methyl-2, 3,3a, 8a-tetrahydrofuro[2,3-b] benzofuran (6a) and (5S)-7Hydroxy-5-methyl-4, 5-dihydro-2, 5-methano-1, 3-benzodioxepine (7a)

Under a nitrogen atmosphere, a solution of compound $2(177 \mathrm{mg}, 0.423 \mathrm{mmol})$ in $2 \mathrm{~mL}$ of ether was dropwise added to lithium aluminum hydride $(32 \mathrm{mg}, 0.843 \mathrm{mmol})$ in ether at $0^{\circ} \mathrm{C}$. The mixture, after stirring at $0^{\circ} \mathrm{C}$ for $0.5 \mathrm{~h}$, was stirred for another one hour at room temperature. Thereafter, $1 \mathrm{M} \mathrm{HCl}$ ether solution and was to provide a mixture of $\mathrm{pH} 3-4$, which then was stirred for 0.5 hour at room temperature. Next, the mixture was filtered and the filtrate was concentrated. The residue was subjected to chromatography on silica gel $($ EtOAc/Hexane $=1 / 3)$ to give $24.4 \mathrm{mg}$ of a mixture of compounds $6 \mathbf{a}$ and 7a. The GC-CI-MS and ${ }^{1} \mathrm{H}-\mathrm{NMR}$ of this mixture were the same as that of the racemic ${ }^{17}$ and showed an approximate $1: 1$ molar ratio of (3aS)-5-hydroxy-3a-methyl-2, 3,3a, 8a-tetrahydrofuro[2,3-b] benzofuran (6a) and (5S)-7hydroxy-5-methyl-4, 5-dihydro-2, 5-methano-1, 3-benzodioxepine (7a). The yields were 30\% and the compounds were directly used as starting material for the next reactions.

(3aR)-5-Hydroxy-3a-methyl-2, 3,3a, 8a-tetrahydrofuro[2,3-b] benzofuran (6b) and (5R)-7Hydroxy-5-methyl-4, 5-dihydro-2, 5-methano-1, 3-benzodioxepine (7b)

Compounds $6 \mathbf{b}$ and $7 \mathbf{b}$ were prepared from compound $\mathbf{3}$, according to the procedure described for compounds $\mathbf{6 a}$ and $7 \mathbf{a}$.

(-)-(3aS)-3a-Methyl-2, 3,3a, 8a-tetrahydrofuro[2,3- $b$ ] benzofuran-5yl $N$-ethyl carbamate (8a) and (-)-(5S)-5-Methyl-4, 5-dihydro-2, 5-methano-1, 3-benzodioxepin-7yl N-ethyl carbamate

(11a)

Under a nitrogen atmosphere, two small pieces of sodium (about $1 \mathrm{mg}$ ) were added into a solution of mixture of $6 \mathbf{a}$ and $7 \mathbf{a}(24.4 \mathrm{mg}, 0.127 \mathrm{mmol})$ in $5 \mathrm{~mL}$ of anhydrous ether at room temperature. This mixture was then stirred for 2 minutes, and ethyl isocyanate $(30.1 \mu \mathrm{L}, 0.381$ $\mathrm{mmol}$ ) was next added to the reaction mixture in one portion. An hour into the reaction at room temperature, $1.4 \mathrm{~mL}$ of water was added and the ether layer was separated. After drying over sodium sulphate and filtering, the filtrate was evaporated to remove solvent. The residue was chromatographed on silica gel plate $(\mathrm{EtOAc} / \mathrm{Hexane}=1 / 3)$ to afford products 8a and 11a. Product 8a (11.6 mg, 69.7\%): $[\alpha]_{\mathrm{D}}{ }^{26}-92.2^{\circ}\left(\mathrm{c}=0.09, \mathrm{CHCl}_{3}\right)$; e.e. $100 \% ;{ }^{1} \mathrm{H}-\mathrm{NMR}\left(\mathrm{CDCl}_{3}\right) \delta$ 6.87-6.60 (m, 3H, Ar-H), 5.77 (s, 1H, C8a-H), 4.89 (s, br, 1H, NH), 4.06-3.56 (m, 2H, C2-H), $3.23\left(\mathrm{~m}, 2 \mathrm{H}, \mathrm{C} 5-\mathrm{CH}_{2} \mathrm{NHCOO}\right), 2.13-1.91(\mathrm{~m}, 2 \mathrm{H}, \mathrm{C} 3-\mathrm{H}), 1.47\left(\mathrm{~s}, 3 \mathrm{H}, \mathrm{C} 3 \mathrm{a}-\mathrm{CH}_{3}\right)$ and $1.14(\mathrm{t}$, $\left.3 \mathrm{H}, \mathrm{C} 5-\mathrm{CH}_{3} \mathrm{CH}_{2} \mathrm{NHCOO}\right) \mathrm{ppm}$; CI-MS $\left(\mathrm{CH}_{4}\right), \mathrm{m} / \mathrm{z}: 264\left(\mathrm{MH}^{+}\right), 193,175$ and 72 . Anal. $\left(\mathrm{C}_{14} \mathrm{H}_{17} \mathrm{~N} \mathrm{O}_{4}\right) \mathrm{N}, \mathrm{H}$; C: Calcd. 63.87; Found 63.14. Product 11a (14.1 mg, 84.6\%): $[\alpha]_{\mathrm{D}}{ }^{25}$ 
$-10.0^{\circ}\left(\mathrm{c}=0.12, \mathrm{CHCl}_{3}\right)$, e.e. $100 \% .{ }^{1} \mathrm{H}-\mathrm{NMR}\left(\mathrm{CDCl}_{3}\right) \delta 6.82-6,67(\mathrm{~m}, 3 \mathrm{H}, \mathrm{Ar}-\mathrm{H}), 5.69(\mathrm{~d}$, $\mathrm{J}=1.80 \mathrm{~Hz}, 1 \mathrm{H}, \mathrm{C} 2-\mathrm{H}), 4.88$ (s, br, $1 \mathrm{H}, \mathrm{C} 7-\mathrm{NHCOO}), 4.17,3.70\left(\mathrm{AB}, \mathrm{J}_{\text {gem }}=7.20 \mathrm{~Hz}, 2 \mathrm{H}, \mathrm{C} 4-\right.$

$\mathrm{H}), 3.22\left(\mathrm{~m}, 2 \mathrm{H}, \mathrm{C}-7 \mathrm{CH}_{2} \mathrm{NHCOO}\right), 2.19-1.19(\mathrm{~m}, 2 \mathrm{H}, \mathrm{C} 10-\mathrm{H}), 1.41\left(\mathrm{~s}, 3 \mathrm{H}, \mathrm{C} 5-\mathrm{CH}_{3}\right)$ and 1.16 (t, 3H, C7- $\left.\mathrm{CH}_{3} \mathrm{CH}_{2} \mathrm{NHCOO}\right) \mathrm{ppm}$; CI-MS $\left(\mathrm{CH}_{4}\right), \mathrm{m} / \mathrm{z}: 264\left(\mathrm{MH}^{+}\right), 246,220,193,175,149$ and 72. Anal. $\left(\mathrm{C}_{14} \mathrm{H}_{17} \mathrm{~N} \mathrm{O}_{4}\right) \mathrm{C}, \mathrm{H}$; N: Calcd. 5.32; Found 4.91.

\section{(+)-(3aR)-3a-Methyl-2, 3,3a, 8a-Tetrahydrofuro[2,3-b] benzofuran-5yl $\mathrm{N}$-ethyl carbamate (8b) and (+)-(5R)-5-Methyl-4, 5-dihydro-2, 5-methano-1, 3-benzodioxepin-7yl $N$-ethyl carbamate (11b)}

Under a nitrogen atmosphere, two small pieces of sodium (about $1 \mathrm{mg}$ ) were added into a solution of mixture of $\mathbf{6 b}$ and $7 \mathbf{b}(26 \mathrm{mg}, 0.135 \mathrm{mmol})$ in $5 \mathrm{~mL}$ of anhydrous ether at room temperature. The mixture was stirred for 2 minutes and, thereafter, ethyl isocyanate $(32.8 \mu \mathrm{L}$, $0.408 \mathrm{mmol}$ ) was added to the reaction mixture in one portion. The reaction was continued for an hour at room temperature, $4.0 \mathrm{~mL}$ of water was then added and the ether layer was separated. After drying over sodium sulphate and filtering, the filtrate was evaporated to remove solvent. Thereafter, the residue was subjected to chromatography on silica gel plate $(\mathrm{EtOAc} / \mathrm{Hexane}=$ $1 / 3)$ to afford products $\mathbf{8 b}$ and $\mathbf{1 1 b}$. Product $8 \mathbf{b}(14.8 \mathrm{mg}, 83.1 \%)$ : $[\alpha]_{\mathrm{D}}{ }^{26}+92.5^{\circ}(\mathrm{c}=0.08$,

$\left.\mathrm{CHCl}_{3}\right)$; e.e. $100 \% ;{ }^{1} \mathrm{H}-\mathrm{NMR}\left(\mathrm{CDCl}_{3}\right) \delta$ 6.87-6.60 (m, 3H, Ar-H), 5.77 (s, $\left.1 \mathrm{H}, \mathrm{C} 8 \mathrm{a}-\mathrm{H}\right), 4.89$ (s, br, 1H, NH), 4.06-3.56 (m, 2H, C2-H), 3.23 (m, 2H, C5-CH $\left.\mathrm{CH}_{2} \mathrm{NHCO}\right), 2.13-1.91(\mathrm{~m}, 2 \mathrm{H}$, $\mathrm{C} 3-\mathrm{H}), 1.47$ (s, 3H, C3a-CH 3 ) and $1.14\left(\mathrm{t}, 3 \mathrm{H}, \mathrm{C} 5-\mathrm{CH}_{3} \mathrm{CH}_{2} \mathrm{NHCOO}\right) \mathrm{ppm}$; CI-MS $\left(\mathrm{CH}_{4}\right), \mathrm{m} /$ z: $264\left(\mathrm{MH}^{+}\right), 193,175$ and 72. Anal. $\left(\mathrm{C}_{14} \mathrm{H}_{17} \mathrm{~N} \mathrm{O}_{4}\right) \mathrm{C}, \mathrm{H} ; \mathrm{N}$ : Calcd. 5.32; Found 4.78. Product $11 \mathrm{~b}(10.4 \mathrm{mg}, 58.4 \%):[\alpha]_{\mathrm{D}}{ }^{26}+10.0^{\circ}\left(\mathrm{c}=0.05, \mathrm{CHCl}_{3}\right)$; e.e. $100 \%$. ${ }^{1} \mathrm{H}-\mathrm{NMR}\left(\mathrm{CDCl}_{3}\right) \delta$ 6.82-6,67(m, 3H, Ar-H), 5.69 (d, J=1.80Hz, 1H, C2-H), 4.88 (s, br, 1H, C7-NHCOO), 4.17, $3.70\left(\mathrm{AB}, \mathrm{J}_{\text {gem }}=7.20 \mathrm{~Hz}, 2 \mathrm{H}, \mathrm{C} 4-\mathrm{H}\right), 3.22\left(\mathrm{~m}, 2 \mathrm{H}, \mathrm{C}-7 \mathrm{CH}_{2} \mathrm{NHCOO}\right), 2.19-1.19(\mathrm{~m}, 2 \mathrm{H}, \mathrm{C} 10-$ $\mathrm{H}), 1.41\left(\mathrm{~s}, 3 \mathrm{H}, \mathrm{C} 5-\mathrm{CH}_{3}\right)$ and $1.16\left(\mathrm{t}, 3 \mathrm{H}, \mathrm{C} 7-\mathrm{CH}_{3} \mathrm{CH}_{2} \mathrm{NHCOO}\right) \mathrm{ppm}$; CI-MS $\left(\mathrm{CH}_{4}\right), \mathrm{m} / \mathrm{z}: 264$ $\left(\mathrm{MH}^{+}\right), 246,220,193,175,149$ and 72 . Anal. $\left(\mathrm{C}_{14} \mathrm{H}_{17} \mathrm{~N} \mathrm{O}_{4}\right) \mathrm{C}, \mathrm{H}, \mathrm{N}$.

\section{(-)-(3aS)-3a-Methyl-2, 3,3a, 8a-Tetrahydrofuro[2,3-b] benzofuran-5yl N-o-tolyl carbamate (9a) and (+)-(5S)-5-Methyl-4, 5-dihydro-2, 5-methano-1, 3-benzodioxepin-7yl N-o-tolyl carbamate (12a)}

Under a nitrogen atmosphere, two small pieces of sodium (about $1 \mathrm{mg}$ ) were added into a solution of mixture of $6 \mathbf{a}$ and $7 \mathbf{a}(27.9 \mathrm{mg}, 0.145 \mathrm{mmol})$ in $5 \mathrm{~mL}$ of anhydrous ether at room temperature. The mixture was stirred for 2 minutes, and then $o$-tolyl isocyanate $(18.9 \mu \mathrm{L}, 0.149$ $\mathrm{mmol}$ ) was added to the mixture in one portion. The reaction was continued for 35 minutes at room temperature, $4 \mathrm{~mL}$ of water then was added and the ether layer was separated. After drying over sodium sulphate and filtering, the filtrate was evaporated to remove solvent. The residue was chromatographed on silica gel plate $(\mathrm{EtOAc} / \mathrm{Hexane}=1 / 3)$ to afford products 9a and 12a. Product 9a $(15.6 \mathrm{mg}, 66.1 \%)$ : $[\alpha]_{\mathrm{D}}{ }^{27}-103.0^{\circ}\left(\mathrm{c}=0.10, \mathrm{CHCl}_{3}\right)$; e.e. $100 \% ;{ }^{1} \mathrm{H}-\mathrm{NMR}$ $\left(\mathrm{CDCl}_{3}\right) \delta 7.84(\mathrm{~s}, \mathrm{br}, 1 \mathrm{H}, \mathrm{NH}), 7.32-6.70(\mathrm{~m}, 7 \mathrm{H}, \mathrm{Ar}-\mathrm{H}), 5.89(\mathrm{~s}, 1 \mathrm{H}, \mathrm{C} 8 \mathrm{a}-\mathrm{H}), 4.18-3.68(\mathrm{~m}$, $2 \mathrm{H}, \mathrm{C} 2-\mathrm{H}), 2.39-2.05(\mathrm{~m}, 2 \mathrm{H}, \mathrm{C} 3-\mathrm{H}), 2.31\left(\mathrm{~s}, 3 \mathrm{H}, \mathrm{Ar}_{-} \mathrm{CH}_{3}\right)$ and 1.56 (s, 3H, C3a-CH $)_{3} \mathrm{ppm}$; CI-MS $\left(\mathrm{CH}_{4}\right), \mathrm{m} / \mathrm{z}: 326\left(\mathrm{MH}^{+}\right)$. Anal. $\left(\mathrm{C}_{19} \mathrm{H}_{19} \mathrm{~N} \mathrm{O}_{4}\right) \mathrm{H}$; Calcd. C, 70.14; N, 4.25; Found C, 69.18; N,3.71. Product 12a $(15.0 \mathrm{mg}, 63.5 \%)$ : $[\alpha]_{\mathrm{D}}{ }^{27}+30.4^{\circ}\left(\mathrm{c}=0.135, \mathrm{CHCl}_{3}\right)$, e.e. $100 \%$; ${ }^{1} \mathrm{H}-\mathrm{NMR}\left(\mathrm{CDCl}_{3}\right) \delta 7.87$ (s, br, $\left.1 \mathrm{H}, \mathrm{C} 7-\mathrm{NHCOO}\right), 7.33-6.70(\mathrm{~m}, 7 \mathrm{H}, \mathrm{Ar}-\mathrm{H}), 5.79(\mathrm{~d}$, $\mathrm{J}=1.80 \mathrm{~Hz}, 1 \mathrm{H}, \mathrm{C} 2-\mathrm{H}), 4.22,3.79\left(\mathrm{AB}, \mathrm{J}_{\text {gem }}=6.84 \mathrm{~Hz}, 2 \mathrm{H}, \mathrm{C} 4-\mathrm{H}\right), 2.37-2.01(\mathrm{~m}, 2 \mathrm{H}, \mathrm{C} 10-\mathrm{H})$, $2.31\left(\mathrm{~s}, 3 \mathrm{H}, \mathrm{Ar}-\mathrm{CH}_{3}\right)$ and $1.51\left(\mathrm{~s}, 3 \mathrm{H}, \mathrm{C} 5-\mathrm{CH}_{3}\right) \mathrm{ppm} ; \mathrm{CI}-\mathrm{MS}\left(\mathrm{CH}_{4}\right), \mathrm{m} / \mathrm{z}: 326\left(\mathrm{MH}^{+}\right)$. Anal. $\left(\mathrm{C}_{19} \mathrm{H}_{19} \mathrm{~N} \mathrm{O}_{4}\right) \mathrm{C}$; H: Calcd. 5.89; Found 6.36; N: Calcd. 4.31; Found 3.57. 
(+)-(3aR)-3a-Methyl-2, 3,3a, 8a-Tetrahydrofuro[2,3-b] benzofuran-5yl $N$-o-tolyl carbamate (9b) and (-)-(5R)-5-Methyl-4, 5-dihydro-2, 5-methano-1, 3-benzodioxepin-7yl N-o-tolyl carbamate (12b)

Under a nitrogen atmosphere, two small pieces of sodium (about $1 \mathrm{mg}$ ) were added into a solution of mixture of $\mathbf{6 b}$ and $7 \mathbf{b}(18 \mathrm{mg}, 0.09 \mathrm{mmol})$ in $5 \mathrm{~mL}$ of anhydrous ether at room temperature. The mixture was stirred for 2 minutes, and then $o$-tolyl isocyanate $(18.3 \mu \mathrm{L}, 0.145$ $\mathrm{mmol}$ ) was added in one portion. The reaction was continued for a further 35 minutes at room temperature, $4 \mathrm{~mL}$ of water then was added and the ether layer was separated. After drying over sodium sulphate and filtering, the filtrate was evaporated to remove solvent. The residue was chromatographed on silica gel plate $(\mathrm{EtOAc} / \mathrm{Hexane}=1 / 3)$ to afford products $\mathbf{9 b}$ and 12b. Product 9b $(11.0 \mathrm{mg}, 74.9 \%),[\alpha]_{\mathrm{D}}{ }^{26}+104.2^{\circ}\left(\mathrm{c}=0.095, \mathrm{CHCl}_{3}\right)$; e.e. $100 \% ;{ }^{1} \mathrm{H}-\mathrm{NMR}$ $\left(\mathrm{CDCl}_{3}\right) \delta 7.84(\mathrm{~s}, \mathrm{br}, 1 \mathrm{H}, \mathrm{NH}), 7.32-6.70(\mathrm{~m}, 7 \mathrm{H}, \mathrm{Ar}-\mathrm{H}), 5.89(\mathrm{~s}, 1 \mathrm{H}, \mathrm{C} 8 \mathrm{a}-\mathrm{H}), 4.18-3.68(\mathrm{~m}$, $2 \mathrm{H}, \mathrm{C} 2-\mathrm{H}), 2.39-2.05(\mathrm{~m}, 2 \mathrm{H}, \mathrm{C} 3-\mathrm{H}), 2.31\left(\mathrm{~s}, 3 \mathrm{H}, \mathrm{Ar}_{-} \mathrm{CH}_{3}\right)$ and $1.56\left(\mathrm{~s}, 3 \mathrm{H}, \mathrm{C} 3 \mathrm{a}-\mathrm{CH}_{3}\right) \mathrm{ppm}$; CI-MS $\left(\mathrm{CH}_{4}\right), \mathrm{m} / \mathrm{z}: 326\left(\mathrm{MH}^{+}\right)$. Anal. $\left(\mathrm{C}_{19} \mathrm{H}_{19} \mathrm{~N} \mathrm{O}_{4}\right) \mathrm{C}, \mathrm{H} ; \mathrm{N}$ : Calcd. 4.31; Found 3.78. Product 12b $(9.5 \mathrm{mg}, 64.4 \%),[\alpha]_{\mathrm{D}}{ }^{27}-29.0^{\circ}\left(\mathrm{c}=0.10, \mathrm{CHCl}_{3}\right)$; e.e. $100 \%$; ${ }^{1} \mathrm{H}-\mathrm{NMR}\left(\mathrm{CDCl}_{3}\right) \delta 7.87(\mathrm{~s}$, br, 1H, C7-NHCOO), 7.33-6.70 (m, 7H, Ar-H), 5.79 (d, J=1.80Hz, 1H, C2-H), 4.22, 3.79 (AB, $\left.\mathrm{J}_{\text {gem }}=6.84 \mathrm{~Hz}, 2 \mathrm{H}, \mathrm{C} 4-\mathrm{H}\right), 2.37-2.01(\mathrm{~m}, 2 \mathrm{H}, \mathrm{C} 10-\mathrm{H}), 2.31\left(\mathrm{~s}, 3 \mathrm{H}, \mathrm{Ar}-\mathrm{CH}_{3}\right)$ and $1.51(\mathrm{~s}, 3 \mathrm{H}$, C5- $\left.\mathrm{CH}_{3}\right)$ ppm; CI-MS $\left(\mathrm{CH}_{4}\right), \mathrm{m} / \mathrm{z}: 326\left(\mathrm{MH}^{+}\right)$. Anal. $\left(\mathrm{C}_{19} \mathrm{H}_{19} \mathrm{~N} \mathrm{O} \mathrm{O}_{4}\right) \mathrm{N}$; Calcd. C, 70.14; N, 5.89; Found C, 69.49; N, 5.46.

\section{(-)-(3aS)-3a-Methyl-2, 3,3a, 8a-Tetrahydrofuro[2,3-b] benzofuran-5yl N-p-isopropylphenyl carbamate (10a) and (+)-(5S)-5-Methyl-4, 5-dihydro-2, 5-methano-1, 3-benzodioxepin-7yl $\mathrm{N}$ - p-isopropylphenyl carbamate (13a)}

Under a nitrogen atmosphere, two small pieces of sodium (about $1 \mathrm{mg}$ ) were added into a solution of mixture of $6 \mathbf{a}$ and $7 \mathbf{a}(16 \mathrm{mg}, 0.083 \mathrm{mmol})$ in $5 \mathrm{~mL}$ of anhydrous ether at room temperature. The mixture was stirred for 2 minutes and $p$-isopropylphenyl isocyanate $(14 \mu \mathrm{L}$, $0.086 \mathrm{mmol}$ ) was added to the mixture of $\mathbf{6 a}$ and $7 \mathbf{a}$ in one portion. The reaction was continued for an additional 45 minutes at room temperature; thereafter, $4 \mathrm{~mL}$ of water was added and the ether layer separated. After drying over sodium sulphate and filtering, the filtrate was evaporated to remove solvent. The residue was chromatographed on silica gel plate (EtOAc/ Hexane $=1 / 3)$ to afford products 10a and 13a. Product 10a $(8 \mathrm{mg}, 54.4 \%):[\alpha]_{\mathrm{D}}{ }^{26}-91.4^{\circ}$ $\left(\mathrm{c}=0.35, \mathrm{CHCl}_{3}\right)$; e.e.100\%; ${ }^{1} \mathrm{H}-\mathrm{NMR}\left(\mathrm{CDCl}_{3}\right) \delta$ 7.31-6.71 (m, 8H, Ar-H, HNCOO), 5.80 (s, $1 \mathrm{H}, \mathrm{C} 8 \mathrm{a}-\mathrm{H}), 4.09-3.59$ (m, 2H, C2-H), 2.82 (septet, J=5.24Hz, 1H, CHMe 2 ), 2.19-1.96 (m, $2 \mathrm{H}, \mathrm{C} 3-\mathrm{H}), 1.49$ (s, 3H, C3a-CH ${ }_{3}$ and $1.18\left(\mathrm{~d}, \mathrm{~J}=5.24 \mathrm{~Hz}, 6 \mathrm{H}, \mathrm{CH}_{3} \mathrm{CCH}_{3}\right) \mathrm{ppm}$; CI-MS $\left(\mathrm{CH}_{4}\right), \mathrm{m} / \mathrm{z}: 354\left(\mathrm{MH}^{+}\right)$. Anal. $\left(\mathrm{C}_{21} \mathrm{H}_{23} \mathrm{~N} \mathrm{O}_{4}\right) \mathrm{H}$; Calcd. C, 71.37; N, 3.94; Found C, 70.86; N, 3.30. Product 13a $(9 \mathrm{mg}, 61.2 \%)$ : $[\alpha]_{\mathrm{D}}{ }^{26}+50.0^{\circ}\left(\mathrm{c}=0.2, \mathrm{CHCl}_{3}\right)$; e.e. $100 \% ;{ }^{1} \mathrm{H}-\mathrm{NMR}$ $\left(\mathrm{CDCl}_{3}\right) \delta$ 7.30-6.72 (m, 8H, Ar-H, HNCOO), $5.71(\mathrm{~d}, \mathrm{~J}=1.80 \mathrm{~Hz}, 1 \mathrm{H}, \mathrm{C} 2-\mathrm{H}), 4.17,3.70(\mathrm{AB}$, $\left.\mathrm{J}_{\text {gem }}=5.40 \mathrm{~Hz}, 2 \mathrm{H}, \mathrm{C} 4-\mathrm{H}\right), 2.81$ (septet, $\left.\mathrm{J}=5.22 \mathrm{~Hz}, 1 \mathrm{H}, \mathrm{CHMe}_{2}\right), 2.19-1.94(\mathrm{~m}, 2 \mathrm{H}, \mathrm{C} 10-\mathrm{H})$, $1.48\left(\mathrm{~s}, 3 \mathrm{H}, \mathrm{C} 5-\mathrm{CH}_{3}\right)$ and $1.19\left(\mathrm{~d}, \mathrm{~J}=5.22 \mathrm{~Hz}, 6 \mathrm{H}, \mathrm{CH}_{3} \mathrm{CCH}_{3}\right) \mathrm{ppm}$; CI-MS $\left(\mathrm{CH}_{4}\right), \mathrm{m} / \mathrm{z}: 354$ $\left(\mathrm{MH}^{+}\right)$. Anal. $\left(\mathrm{C}_{21} \mathrm{H}_{23} \mathrm{~N} \mathrm{O}_{4}\right) \mathrm{C}, \mathrm{H}$; N: Calcd. 3.96; Found 4.56.

\section{(+)-(3aR)-3a-Methyl-2, 3,3a, 8a-Tetrahydrofuro[2,3-b] benzofuran-5yl $N$ - $p$-isopropylphenyl carbamate (10b) and (-)-(5R)-5-Methyl-4, 5-dihydro-2, 5-methano-1, 3-benzodioxepin-7yl $N$ - p-isopropylphenyl carbamate (13b)}

Under a nitrogen atmosphere, two small pieces of sodium (approx.1 mg) were added into a solution of mixture of $\mathbf{6 b}$ and $\mathbf{7 b}(18 \mathrm{mg}, 0.094 \mathrm{mmol})$ in $5 \mathrm{~mL}$ of anhydrous ether at room temperature. The mixture was stirred for 2 minutes, and then $p$-isopropylphenyl isocyanate $(14.6 \mu \mathrm{L}, 0.096 \mathrm{mmol})$ was added in one portion. The reaction was continued for a further 45 minutes at room temperature, and then $4 \mathrm{~mL}$ of water was added and the ether layer separated. After drying over sodium sulphate and filtering, filtrate was evaporated to remove solvent. The residue was chromatographed on silica gel plate $(\mathrm{EtOAc} / \mathrm{Hexane}=1 / 3)$ to afford products 
10b and 13b. Product 10b $(13.7 \mathrm{mg}, 82.1 \%)$ : $[\alpha]_{\mathrm{D}}{ }^{27}+91.4^{\circ}\left(\mathrm{c}=0.14, \mathrm{CHCl}_{3}\right)$; e.e. $100 \%$; ${ }^{1} \mathrm{H}-$ NMR $\left(\mathrm{CDCl}_{3}\right) \delta$ 7.31-6.71 (m, 8H, Ar-H, HNCOO), $5.80(\mathrm{~s}, 1 \mathrm{H}, \mathrm{C} 8 \mathrm{a}-\mathrm{H}), 4.09-3.59(\mathrm{~m}, 2 \mathrm{H}$, C2-H), 2.82 (septet, J=5.24Hz, 1H, CHMe $)$, 2.19-1.96 (m, 2H, C3-H), 1.49 (s, 3H, C3a$\left.\mathrm{CH}_{3}\right)$ and $1.18\left(\mathrm{~d}, \mathrm{~J}=5.24 \mathrm{~Hz}, 6 \mathrm{H}, \mathrm{CH}_{3} \mathrm{CCH}_{3}\right) \mathrm{ppm}$; CI-MS $\left(\mathrm{CH}_{4}\right), \mathrm{m} / \mathrm{z}: 354\left(\mathrm{MH}^{+}\right)$. Anal. $\left(\mathrm{C}_{21} \mathrm{H}_{23} \mathrm{~N} \mathrm{O}_{4} .1 / 8 \mathrm{H}_{2} \mathrm{O}\right) \mathrm{C}, \mathrm{H}, \mathrm{N}$. Product 13b $(10.1 \mathrm{mg}, 60.4 \%)$ : $[\alpha]_{\mathrm{D}}{ }^{27}-48.0^{\circ}(\mathrm{c}=0.1$, $\mathrm{CHCl}_{3}$ ); e.e. $100 \% ;{ }^{1} \mathrm{H}-\mathrm{NMR}\left(\mathrm{CDCl}_{3}\right) \delta$ 7.30-6.72 (m, 8H, Ar-H, $\left.\mathrm{HNCOO}\right), 5.72(\mathrm{~d}, \mathrm{~J}=1.80 \mathrm{~Hz}$, $1 \mathrm{H}, \mathrm{C} 2-\mathrm{H}), 4.17,3.70\left(\mathrm{AB}, \mathrm{J}_{\text {gem }}=5.40 \mathrm{~Hz}, 2 \mathrm{H}, \mathrm{C} 4-\mathrm{H}\right), 2.81$ (septet, J=5.22 Hz, 1H, CHMe 2 ), 2.19-1.94 (m, 2H, C10-H), $1.48\left(\mathrm{~s}, 3 \mathrm{H}, \mathrm{C} 5-\mathrm{CH}_{3}\right)$ and $1.19\left(\mathrm{~d}, \mathrm{~J}=5.22 \mathrm{~Hz}, 6 \mathrm{H}, \mathrm{CH}_{3} \mathrm{CCH}_{3}\right) \mathrm{ppm}$; CI-MS $\left(\mathrm{CH}_{4}\right), \mathrm{m} / \mathrm{z}: 354\left(\mathrm{MH}^{+}\right)$. Anal. $\left(\mathrm{C}_{21} \mathrm{H}_{23} \mathrm{~N} \mathrm{O}_{4}\right) \mathrm{H}, \mathrm{N}$; C: Calcd. C 71.37; Found 70.75.

\section{(+)-(3aR)-1,3a, 8-Trimethyl-1, 2,3,3a, 8,8a-hexahydropyrrolo[2,3-b] indol-5ol (14b)}

Compound 14b was synthesized, according to the procedure for its enantiomer, from Nmethylphenetidine. ${ }^{14}$

\section{(+)-(3aR)-1,3a, 8-Trimethyl-1, 2,3,3a, 8,8a-hexahydropyrrolo[2,3-b] indol-5yl N- (2'- methylphenyl) carbamate (17b)}

Compound $\mathbf{1 7 b}$ was made, according to the procedure for its antipode, from o-tolyl isocyanate and (+)-eseroline: ${ }^{21}[\alpha]_{\mathrm{D}}{ }^{26}+68.2^{\circ}\left(\mathrm{c}=0.2, \mathrm{CHCl}_{3}\right) ;{ }^{1} \mathrm{H}$ NMR and MS were the same as reported for its enantiomer. ${ }^{21}$ Anal. $\left(\mathrm{C}_{21} \mathrm{H}_{25} \mathrm{~N}_{3} \mathrm{O}_{2}\right) \mathrm{H}$; Calcd. C, 71.70; N, 11.95; Found $\mathrm{C}$, $70.08 ; \mathrm{N}, 11.45$.

\section{(+)-(3aR)- 1, 3a, 8-Trimethyl-1, 2,3,3a, 8,8a-hexahydropyrrolo[2,3-b] indol-5yl N- (4'-} isopropylphenyl) carbamate (18b)

Compound $18 \mathrm{~b}$ was synthesized, according to the procedure for its antipode, from $p$ isopropylphenyl isocyanate and (+)-eseroline: ${ }^{21}[\alpha]_{\mathrm{D}}{ }^{26}+67.5^{\circ}\left(\mathrm{c}=0.2, \mathrm{CHCl}_{3}\right) ;{ }^{1} \mathrm{H}$ NMR and MS were the same as reported for its enantiomer. ${ }^{21}$ Anal. $\left(\mathrm{C}_{23} \mathrm{H}_{29} \mathrm{~N}_{3} \mathrm{O}_{2}\right) \mathrm{H}, \mathrm{N}$; C: Calcd. 72.79; Found 71.70.

(+)-(3aR)-3a, 8-Dimethyl-2, 3,3a, 8a-tetrahydrofuro[2,3-b] indol-5-ol (19b) Compound $19 \mathrm{~b}$ made according to the procedure for synthesis of its enantiomer. ${ }^{14,} 17$

(+)-(3aR)-3a, 8-Dimethyl-2, 3,3a, 8a-tetrahydrofuro[2,3-b] indol-5-yl N- (2'-methylphenyl) carbamate (22b)

Compound 22b was synthesized, according to the procedure for its antipode, from o-tolyl isocyanate and (+)-eseroline: ${ }^{21}[\alpha]_{\mathrm{D}}{ }^{26}+27.5^{\circ}\left(\mathrm{c}=0.2, \mathrm{CHCl}_{3}\right) ;{ }^{1} \mathrm{H}$ NMR and MS were the same as reported for its enantiomer. ${ }^{20}$ Anal. $\left(\mathrm{C}_{20} \mathrm{H}_{22} \mathrm{~N}_{2} \mathrm{O}_{3}\right) \mathrm{C}, \mathrm{H} ; \mathrm{N}$ : Calcd. 8.28; Found 7.84

\section{(+)-(3aR)-3a, 8-Dimethyl-2, 3,3a, 8a-tetrahydrofuro[2,3-b] indol-5-yl $\mathrm{N}$ - (4'-isopropylphenyl) carbamate (23b)}

Compound $\mathbf{2 3 b}$ was made, according to the procedure for its antipode, from $p$-isopropylphenyl isocyanate and (+)-eseroline: ${ }^{16}[\alpha]_{\mathrm{D}}{ }^{26}+32.0^{\circ}\left(\mathrm{c}=0.2, \mathrm{CHCl}_{3}\right) ;{ }^{1} \mathrm{H}$ NMR and MS were the same as reported for its enantiomer. ${ }^{17}$ Anal. $\left(\mathrm{C}_{22} \mathrm{H}_{26} \mathrm{~N}_{2} \mathrm{O}_{3}\right) \mathrm{C}, \mathrm{H} ; \mathrm{N}$ : Calcd. 7.64; Found 7.13.

\section{X-ray Crystallography}

A clear colorless crystal of dimensions $0.30 \times 0.23 \times 0.12 \mathrm{~mm}^{2}$ was mounted on glass fiber using a small amount of Epoxy. Data were collected on a Bruker three-circle platform diffractometer equipped with a SMART $6000 \mathrm{CCD}$ detector. The crystals were irradiated using a rotating anode $\mathrm{CuK}_{\alpha}$ source $(\lambda=1.54178)$ with incident beam Göbel mirrors. Data collection was performed and the unit cell was initially refined using SMART[v5.625]. 53(a) Data Reduction was performed using SAINT [v6.36A] ${ }^{53(\mathrm{~b})}$ and XPREP [v6.12]. ${ }^{53(\mathrm{c})}$ Corrections 
were applied for Lorentz, polarization, and absorption effects using SADABS [v2.03]. $53(\mathrm{~d})$ The structure was solved and refined with the aid of the programs in the SHELXTL-plus [v6.10] system of programs. ${ }^{53(\mathrm{e})}$ The full-matrix least-squares refinement on $\mathrm{F}^{2}$ included atomic coordinates and anisotropic thermal parameters for all non- $\mathrm{H}$ atoms. The $\mathrm{H}$ atoms were included using a riding model. The absolute configuration of $\mathrm{C} 3$ was established by making reference to unchanging chiral centers $(\mathrm{C} 19, \mathrm{C} 21$, and $\mathrm{C} 24)$ in the synthetic procedure, with a resulting Flack parameter of -0.3(2). 53(f) The X-ray data of compound 3 also can be found at the Cambridge Crystallographic Data Center (CCDC), <http://www.ccdc.cam.ac.uk/ >. The reference number of this crystal is 285734 .

\section{Quantitation of anticholinesterase activity}

The action of enantiomers $8-\mathbf{1 3}$ and compounds $\mathbf{1 7 b}, \mathbf{1 8 b}, \mathbf{2 2 b}$ and $\mathbf{2 3 b}$ to inhibit the ability of freshly prepared human $\mathrm{AChE}$ and $\mathrm{BChE}$ to enzymatically degrade their respective specific substrates, acetyl-( $\beta$-methyl)thiocholine and $s$-butyrylthiocholine $(0.5 \mathrm{mmol} / \mathrm{L})($ Sigma Chemical Co., St. Lois, MO), was quantified. ${ }^{13-17,19-21}$ Samples of AChE and BChE were derived from freshly collected human whole red blood cells and plasma, respectively. Compounds were dissolved in Tween 80/EtOH 3:1 ( $v: v ;<150 \mu \mathrm{L}$ total volume) and were diluted in $0.1 \mathrm{M} \mathrm{Na}_{3} \mathrm{PO}_{4}$ buffer $(\mathrm{pH} 8.0)$ in half-log concentrations to provide a final concentration range that spanned $0.3 \mathrm{nM}$ to $30 \mathrm{uM}$. Tween $80 / \mathrm{EtOH}$ was diluted to in excess of 1 in 5000. No inhibitory action on either AChE or BChE was detected in separate experiments where the ChEI activity of the known compound 15a was quantified in excess and without Tween 80/EtOH.

For the preparation of $\mathrm{BChE}$, freshly collected blood was centrifuged $\left(10,000 \mathrm{~g}, 10 \mathrm{~min}, 4^{\circ} \mathrm{C}\right)$ and plasma was removed and diluted 1:125 with $0.1 \mathrm{M} \mathrm{Na}_{3} \mathrm{PO}_{4}$ buffer ( $\mathrm{pH}$ 7.4). Plasma was carefully checked to insure an absence of haemolysis. For AChE preparation, erythrocytes were washed five times in isotonic saline, lysed in 9 volumes of $0.1 \mathrm{M} \mathrm{Na}_{3} \mathrm{PO}_{4}$ buffer $(\mathrm{pH} 7.4)$ containing $0.5 \%$ Triton- $X$ (Sigma) and then were diluted with an additional 19 volumes of buffer to a final dilution of 1:200.

Analysis of anticholinesterase activity was undertaken by utilizing a $25 \mu \mathrm{L}$ sample of each enzyme preparation, and was undertaken at their optimal working $\mathrm{pH}, 8.0$, in $0.1 \mathrm{M} \mathrm{Na}_{3} \mathrm{PO}_{4}$ buffer $(0.75 \mathrm{~mL}$ total volume). Compounds were preincubated with enzymes ( $30 \mathrm{~min}$, at room temperature) and then were incubated with their respective substrates and with 5,5'-dithiobis-2nitrobenzoic acid $\left(25 \mathrm{~min}, 37^{\circ} \mathrm{C}\right)$. The substrate/enzyme interaction was immediately halted by the addition of excess enzyme inhibitor (physostigmine $1 \times 10^{-5} \mathrm{M}$ ) and production of a yellow thionitrobenzoate anion was then measured by spectrophotometer at $412 \mathrm{~nm} \lambda$. To correct for nonspecific substrate hydrolysis, aliquots were co-incubated under conditions of absolute enzyme inhibition (by the addition of $1 \times 10^{-5} \mathrm{M}$ physostigmine (15a)), and the associated alteration in absorbance was subtracted from that observed through the concentration range of each test compound. Each agent was analyzed on four separate occasions and assayed along-side physostigmine (15a), as a control and external standard whose activity we have previously reported. ${ }^{13-17,19-21}$ The mean enzyme activity at each concentration of test compound was then expressed as a percent of the activity in the absence of compound. This was transformed into a logit format (where logit $=\ln (\%$ activity $/ 100$ minus $\%$ activity)) and then was plotted as a function of its $\log$ concentration. Inhibitory activity was calculated as an $\mathrm{IC}_{50}$, defined as the concentration of compound (nM) required to inhibit 50\% of enzymatic activity, which was determined from a correlation between log concentration and logit activity. Only results obtained from correlation coefficients of $\mathrm{r}^{2} \geq-0.98$ were considered acceptable. Studies that did not obtain this threshold were repeated. 


\section{Computer Aided Molecular Modeling}

Computer aided molecular modeling was undertaken using Sybyl version 7.0 (Tripos Inc., St. Louis, MO). The numbering of the amino acid residues is based on that for $T c \mathrm{AChE}$. Molecular volume calculations were performed by using multiple volume comparison routine. The atomic coordinates of the transition state of $T c \mathrm{AChE}$ were obtained from the protein data bank (PDB entry: $1 \mathrm{AMN})^{38}$, and were used for transition state studies. In undertaking this, i) molecules of water were removed, ii) the small molecule, $\mathrm{m}$ - ( $N, N, N$-trimethylammonio)-2,2,2trifluoroacetophenone (TMTFA), was extracted and, iii), the carbonyl carbon of TMTFA was retained in the tetrahedral conformation. iv) The carbonyl carbon of the inhibitor, (-)-(3aS)N-2'-methylphenyl carbamoyl phenol of furobenzofuran (9a), was modified into the tetrahedral conformation and then superimposed with that of TMTFA, keeping both phenyl groups on the same side and, as much as possible, in a superimposed conformation. Thereafter, compound 9a was merged into the active domain of $T c \mathrm{AChE}$. The covalent bond between carbonyl carbon of compound $\mathbf{9 a}$ and $\gamma-\mathrm{O}$ of $\mathrm{Ser}_{200}$ was created. To maintain the hydrogen bonds associated with acylation, the distances between the $\mathrm{NH}$ of $\mathrm{Gly}_{118}, \mathrm{Gly}_{119}, \mathrm{Ala}_{201}$ and oxygen of the ligand carbonyl, $\gamma-\mathrm{O}$ of $\mathrm{Ser}_{200}$ and a single $\mathrm{H}$, the hydrogen and $\mathrm{N}$ of $\mathrm{His}_{440}$, the $\mathrm{NH}$ of $\mathrm{His}_{440}$ and oxygen of $\mathrm{Glu}_{327}$ were constrained. All the residues outside a radius of 10 $\AA$ from the compound 9a were aggregated. The energy of the enzyme-inhibitor complex was minimized with the conjugate gradient algorithm.

\section{Supplementary Material}

Refer to Web version on PubMed Central for supplementary material.

\section{Acknowledgement}

The authors are grateful to the Medicinal Chemistry Section, National Institute on Drug Abuse, NIH, for use of chemical characterization and molecular modeling equipment. The research was supported, in part, by the Intramural Research Program of the National Institute on Aging, NIH. Weiming Luo and Qian-sheng Yu are supported via the MedStar Research Institute, Baltimore, MD, and Santosh S. Kulkarni is supported through a National Institutes of Health Visiting Fellowship. Debomoy Lahiri is funded via NIH grants (AG18379 and AG 18884) and the Alzheimer's Association.

\section{REFERENCE}

1. Drachman DA, Leavitt J. Human memory and the cholinergic system. A relationship to aging? Arch Neurol 1974;30:113-121. [PubMed: 4359364]

2. Small DH. Do acetylcholinesterase inhibitors boost synaptic scaling in Alzheimer's disease? Trends Neurosci 2004;27:245-249. [PubMed: 15111005]

3. Lahiri DK, Rogers JT, Sambamurti K, Greig NH. Rationale for the development of cholinesterase inhibitors as anti-Alzheimer agents. Curr Pharm Des 2004;10:3111-3119. [PubMed: 15544501]

4. Cummings JL. Cholinesterase inhibitors: A new class of psychotropic compounds. Am J Psychiatry 2000;157:4-15. [PubMed: 10618007]

5. Courtney C, Farrell D, Gray R, Hills R, Lynch L, Sellwood E, Edwards S, Hardyman W, Raftery J, Crome P, Lendon C, Shaw H, Bentham P. AD2000 Collaborative Group. Long-term donepezil treatment in 565 patients with Alzheimer's disease (AD2000): randomised double-blind trial. Lancet 2004;363(9427):2105-2115. [PubMed: 15220031]

6. Lopez OL, Becker JT, Saxton J, Sweet RA, Klunk W, DeKosky ST. Alteration of a clinically meaningful outcome in the natural history of Alzheimer's disease by cholinesterase inhibition. J Am Geriatr Soc 2005;53:83-87. [PubMed: 15667381]

7. Conworth, E. The Alkaloids. Manskel, RHF., editor. Vol. 8. New York: Academic; 1965. p. 27-46.

8. Robinson, B. The Alkaloids. Manskel, RHF., editor. Vol. 10. New York: Academic; 1967. p. 383-401.and 1971, Vol.13, pp 213 - 226 
9. Brossi A. Bioactive Alkaloids. 4. Results of Recent Investigations with Colchicine and Physostigmine. J. Med. Chem 1990;33:2311-2319. [PubMed: 2202827]

10. Greig NH, Pei XF, Soncrant TT, Ingram DK, Brossi A. Phenserine and Ring C Hetero-Analogues: Drug Candidates for Treatment of Alzheimer's Disease. Med. Res. Rev 1995;15:3-31. [PubMed: 7898167]

11. Greig NH, Sambamurti K, Yu QS, Brossi A, Bruinsma G, Lahiri DK. An overview of phenserine tartrate, a novel acetylcholinesterase inhibitor for the treatment of Alzheimer's disease. Cur. Alz. Res 2005;2:281-291.

12. Greig, NH.; Sambamurti, K.; Yu, QS.; Perry, TA.; Holloway, HW.; Haberman, F.; Brossi, A.; Ingram, DK.; Lahiri, DK. Butyrylcholinesterase: its selective inhibition and relevance to Alzheimer's disease. In: Giacobini, E., editor. Butyrylcholinesterase: Its Function and Inhibition. London: Martin Dunitz Ltd.; 2003. p. 69-90.

13. Pei XF, Greig NH, Bi S, Broosi A, Toome V. Inhibition of Human Acetylcholinesterase by Unnatural (+)-(3aR)-N1-Norphysostigmine and Arylcarbamate analogues. Med. Chem. Res 1995;5:265-270.

14. Yu QS, Luo W, Holloway HW, Utsuki T, Perry TA, Lahiri DK, Greig NH, Brossi A. Racemic $N^{1}$ Norphenserine and Its Enantiomers: Unpredicted Inhibition of Human Acetyl- and Butylylcholinesterase and $\beta$-Amyloid Precursor Protein in vitro Heterocycles 2003;619:529-539.

15. Yu QS, Liu C, Brzostowska M, Chrisey L, Brossi A, Greig NH. Physovenines: Efficient Synthesis of (-)- and (+)-Physovenine and Synthesis of Carbamate Analogues of (-)-Physovenine.

Anticholinesterase Activity and Analgesic Properties of Optically Active Physovenines. Helvetica Chimica Acta 1991;74:761-766.

16. Brzostowska M, He XS, Greig NH, Rapoport S, Brossi A. Phenylcarbamates of (-)- Eceroline and (-)-Physovenol: Selective Inhibition of Acetyl and, or Butyrylcholinesterases by Phenylcarbamates. Med. Chem. Res 1992;2:238-246.

17. Luo W, Yu QS, Zhan M, Parrish D, Deschamps JR, Kulkarrni SS, Holloway HW, Alley GM, Lahiri DK, Brossi A, Greig NH. Novel Acetylcholinesterase based on the Molecular Skeletons of Furobenzofuran and Methanobenzodioxepine. J. Med. Chem 2005;48:986-994. [PubMed: 15715468]

18. Luo W, Yu QS, Holloway HW, Parrish DA, Greig NG, Brossi A. Syntheses of Tetrahydrofurobenzofurans and Dihydro-methanobenzodioxepines from 5-Hydroxy-3-methyl-3Hbenzofuran-2-one. Rearrangement and Ring Expansion under Reductive Conditions on Treatment with Hydrides. J. Org. Chem 2005;70:6171-6176. [PubMed: 16050674]

19. Yu QS, Holloway HW, Utsuki T, Brossi A, Greig NH. Phenserine-based synthesis of novel selective inhibitors of butyrylcholinesterase for Alzheimer's disease. J. Med. Chem 1999;42:1855-1861. [PubMed: 10346939]

20. Yu QS, Zhu X, Holloway HW, Whittaker NF, Utsuki T, Brossi A, Greig NH. Anticholinesterase activity of compounds related to geneserine tautomers - N-oxides and 1,2-oxazines. J. Med. Chem 2002;45:3684-3691. [PubMed: 12166941]

21. Yu QS, Holloway HW, Flippen-Anderson F, Hoffman B, Brossi A, Greig NH. Methyl analogues of the experimental Alzheimer drug, phenserine: synthesis and structure/activity relationships for acetyl- and butyrylcholinesterase inhibitory action. J. Med. Chem 2001;44:4062-4071. [PubMed: 11708910]

22. Kamal MA, Greig NH, Alhomida AS, Al-Jafari AA. Human acetylcholinesterase inhibition kinetics of the experimental Alzheimer therapeutic, tolserine. Biochem. Pharmacol 2000;60:561-570. [PubMed: 10874131]

23. Al-Jafari AA, Kamal MA, Alhomida AS, Greig NH. Brain acetylcholinesterase inhibition kinetics of two experimental Alzheimer's disease drugs, phenserine and tolserine, in the rat. J.Biochem. Mol. Biol. \& Biophys 2000;4:323-335.

24. Kamal MA, Al-Jafari AA, Greig NH. A new, simple and economical approach to analyze the inhibition kinetics of the enzyme, acetylcholinesterase, by using the experimental Alzheimer drug, tolserine. Emir. Med. J 2002;20:333-337.

25. Marshall, GR.; Barry, CD. Abstr. Am. Cryst. Assoc. Honolulu, HI: 1979. Functional Representation of Molecular Volume for Computer-Aided Drug Design. 
26. Sufrin JR, Dunn DA, Marshall GR. Steric Mapping of The L-Methionine Binding Site of ATP:LMethionine S-Adenosyltransferase. Molecular Pharmacology 1981;19:307-313. [PubMed: 7231391]

27. Brufani, M.; Filocamo, L. Rational design of cholinesterase inhibitors. In: Giacobini, E., editor. Cholinesterases and Cholinesterase Inhibitors. London: Martin Dunitz Ltd.; 2000. p. 27-46.

28. Reiner, E.; Radic, Z. Mechanism of action of cholinesterase inhibitors. In: Giacobini, E., editor. Cholinesterases and Cholinesterase Inhibitors. London: Martin Dunitz Ltd.; 2000. p. 27103-27119.

29. Greenblatt HM, Dvir H, Silman I, Sussman JL. Acetylcholinesterase: a multifaceted target for structure-based drug design of anticholinesterase agents for the treatment of Alzheimer's disease. $\mathbf{J}$ Mol Neurosci 2003;20:369-383. [PubMed: 14501022]

30. Krasiski A, Radi Z, Manetsch R, Raushel J, Taylor P, Sharpless KB, Kolb HC. In Situ Selection of Lead Compounds by Click Chemistry Target-Guided Optimization of Acetylcholinesterase Inhibitors. J. Am. Chem. Soc 2005;127:6686-6692. [PubMed: 15869290]

31. Muñoz-Ruiz P, Rubio L, García-Palomero E, Dorronsoro I, Monte-Millán M, Valenzuela R, Usán P, Austra C, Bartolini M, Andrisano V, Bidon-Chanal A, Orozco M, Luque FJ, Medina M, Martínez A. Design, synthesis and biological evaluation of dual binding site acetylcholinesterase inhibitors: new disease modifying agents for Alzheimer's disease. J. Med. Chem. 2005E-online Oct.

32. Otoguro K, Kuno F, Omura S. Arisugacins, selective acetylcholinesterase inhibitors of microbial origin. Pharmacol Ther 1997;76:45-54. [PubMed: 9535168]

33. Soreq H, Seidman S. Acetylcholinesterase--new roles for an old actor. Nat Rev Neurosci 2001;2:294302. [PubMed: 11283752]

34. Massoulie, J. Molecular forms and anchoring of acetylcholinesterase. In: Giacobini, E., editor. Cholinesterases and Cholinesterase Inhibitors. London: Martin Dunitz Ltd.; 2000. p. 81-102.

35. Soreq H, Gnatt A, Loewenstein Y, Neville LF. Excavations into the active-site gorge of cholinesterases. Trends Biochem Sci 1992;17:353-358. [PubMed: 1412713]

36. Dvir H, Wong DM, Harel M, Barril X, Orozco M, Luque FJ, Munoz-Torrero D, Camps P, Rosenberry TL, Silman I, Sussman JL. 3D structure of Torpedo californica acetylcholinesterase complexed with huprine $\mathrm{X}$ at 2.1 A resolution: kinetic and molecular dynamic correlates. Biochemistry 2002;41:2970-2981. [PubMed: 11863435]

37. Silman I, Millard CB, Ordentlich A, Greenblatt HM, Harel M, Barak D, Shafferman A, Sussman JL. A preliminary comparison of structural models for catalytic intermediates of acetylcholinesterase. Chem Biol Interact 1999;119(120):43-52. [PubMed: 10421437]

38. Silman I, Harel M, Axelsen P, Raves M, Sussman JL. Three-dimensional structures of acetylcholinesterase and of its complexes with anticholinesterase agents. Biochem Soc Trans 1994;22:745-749. [PubMed: 7821677]

39. Nachon F, Asojo OA, Borgstahl GEO, Masson P, Lockridge O. Role of waterin aging of human butylcholinesterase inhibited by echothiophate: the crystal structure suggest two alternative mechanisms of aging. Biochemistry 2005;44:1154. [PubMed: 15667209](PDB codes: 1XLW, 1XLV, 1XLU)

40. Nicolet Y, Lockridg O, Masson P, Fontecilla-Camps JC, Nachon F. Crystal Structure of Human Butyrylcholinesterase and of its Complexes with Substrate and Products. J. Biol. Chem 2003;278:41141. [PubMed: 12869558](PDB codes: 1PO1, 1POM, 1POP, 1POQ)

41. Nachon F, Nicolet Y, Viguié N, Masson P, Fontecilla-Camps JC, Lockridg O. Engineering of a monomeric and low-glycosylated form of human butyrylcholinrsterase: exprassion, purification, characterization and crystallization. Eur. J. Biochem 2002;269:630. [PubMed: 11856322]

42. Inestrosa NC, Sagal JP, Colombres M. Acetylcholinesterase interaction with Alzheimer amyloid beta. Subcell Biochem 2005;38:299-317. [PubMed: 15709485]

43. Porschke D, Creminon C, Cousin X, Bon C, Sussman JL, Silman I. Electrooptical measurements demonstrate a large permanent dipole moment associated with acetylcholinesterase. Biophys J 1996;4:1603-1608. [PubMed: 8785319]

44. Felder CE, Botti SA, Lifson S, Silman I, Sussman JL. External and internal electrostatic potentials of cholinesterase models. J Mol Graph Model 1997;15:318-327. [PubMed: 9640563]335-7

45. Scowen, RL. Transition States of Biochemical Processes. Gandour, RD.; Schowen, RL., editors. New York: Plenum; 1978. p. 555-578. 
46. Harel M, Quinn DQ, Nair HK, Silman I, Sussman JL. The X -ray Structure of a Transition State Analog Complex Reveals the Molecular Origins of the Catalytic Power and Substrate Specificity of Acetylcholinesterase. J Am Chem Soc 1996;118:2340-2346.

47. Perola E, Cellai L, Lamba D, Filocamo L, Brufani M. long Chain Analogs of Physostigmine as Potential Drugs for Alzheimer's Disease: new Insights Into the Mechanism of Action in the Inhibition of Acetylcholinesterase. Biochemistry.Biophys. Acta 1997;1343:41.

48. Bartolucci C, Perola E, Cellai L, Brufani M, Lamba D. "Back Door” Opening Implied by the Crystal Structure of Carbamoylated Acetylcholinesterase. Biochemistry 1999;38:5714. [PubMed: 10231521]

49. Koellner G, Steiner T, Millard CB, Silman I, Sussuman JL. A Neutral Molecule in Cation-binding Site: Specific Binding of a PEG-SH to Acetylcholinesterase from Torpedo californica. J. Mol. Biol 2002;320:721-725. [PubMed: 12095250]

50. Yu QS, Greig NH, Holloway HW, Brossi A. 4'-Hyroxyphenylcarbamates of (3aS)-eseroline and (3aS)-N(1)-noreseroline: potential metabolites of the Alzheimer's anticholinesterase drug phenserine. Heterocycles 1999;50:95-102.

51. Francis PT, Nordberg A, Arnold SE. A preclinical view of cholinesterase inhibitors in neuroprotection: do they provide more than symptomatic benefits in Alzheimer's disease? Trends Pharmacol Sci 2005;26:104-111. [PubMed: 15681028]

52. Hashimoto M, Kazui H, Matsumoto K, Nakano Y, Yasuda M, Mori E. Does donepezil treatment slow the progression of hippocampal atrophy in patients with Alzheimer's disease? Am J Psychiatry 2005; 162:676-682. [PubMed: 15800138]

53. Bruker. SMART v5.625. Madison, Wisconsin, USA: Bruker AXS Inc.; 2001a. Bruker. SAINT v6.36A. Madison, Wisconsin, USA: Bruker AXS Inc.; 2002. Bruker. XPREP v6.12. Madison, Wisconsin, USA: Bruker AXS Inc.; 2001b. Bruker. SADABS v2.03. Madison, Wisconsin, USA: Bruker AXS Inc.; 2000. Bruker. SHELXTL v6.10. Madison, Wisconsin, USA: Bruker AXS Inc.; 2000. (f) Flack HD. Acta Cryst 1983;A39:876-881. 

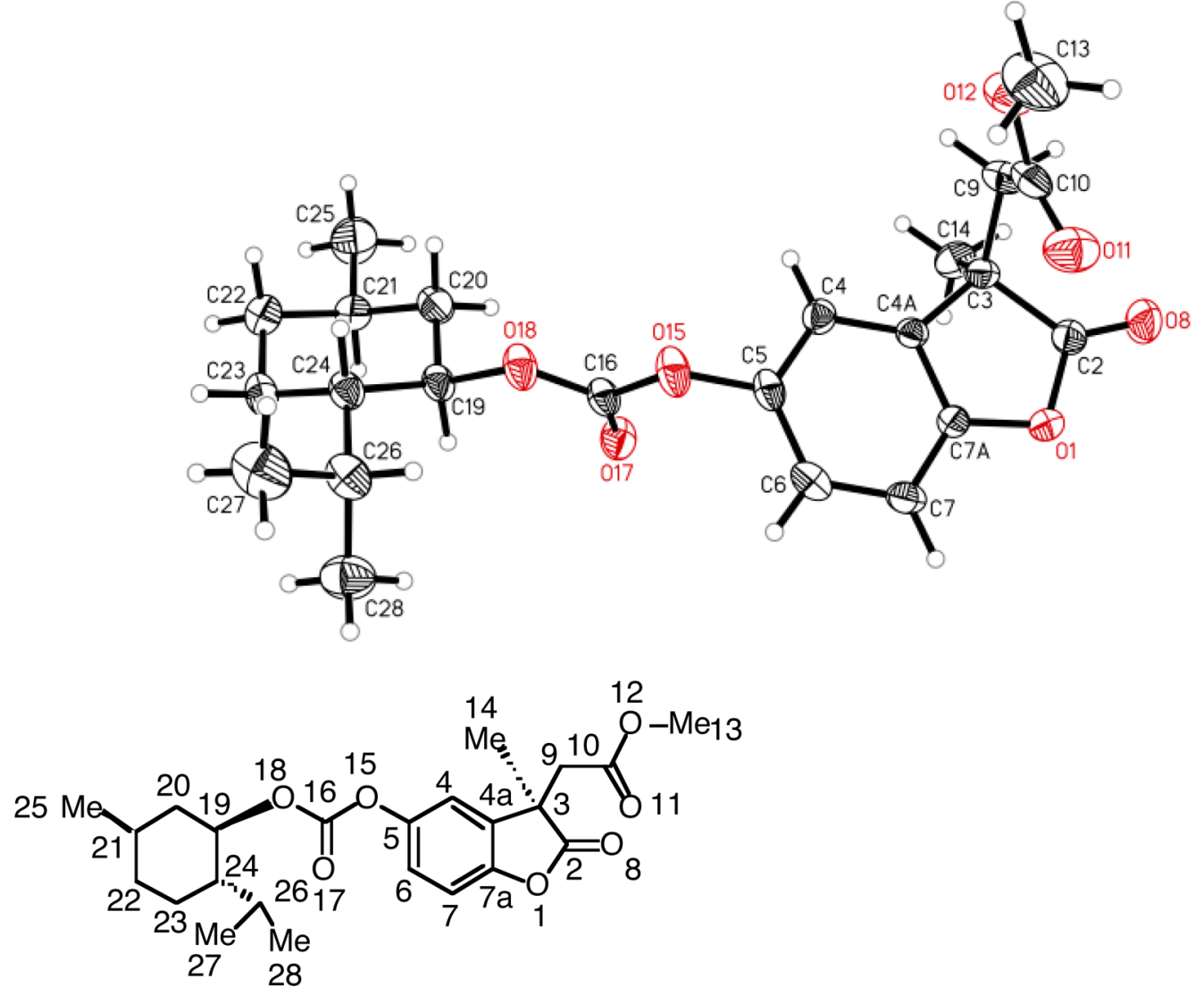

(-)menthyl carbamate (3)

Figure 1.

$\mathrm{X}$-ray crystallographic picture and corresponding chemical structure of $\mathbf{3}$ 

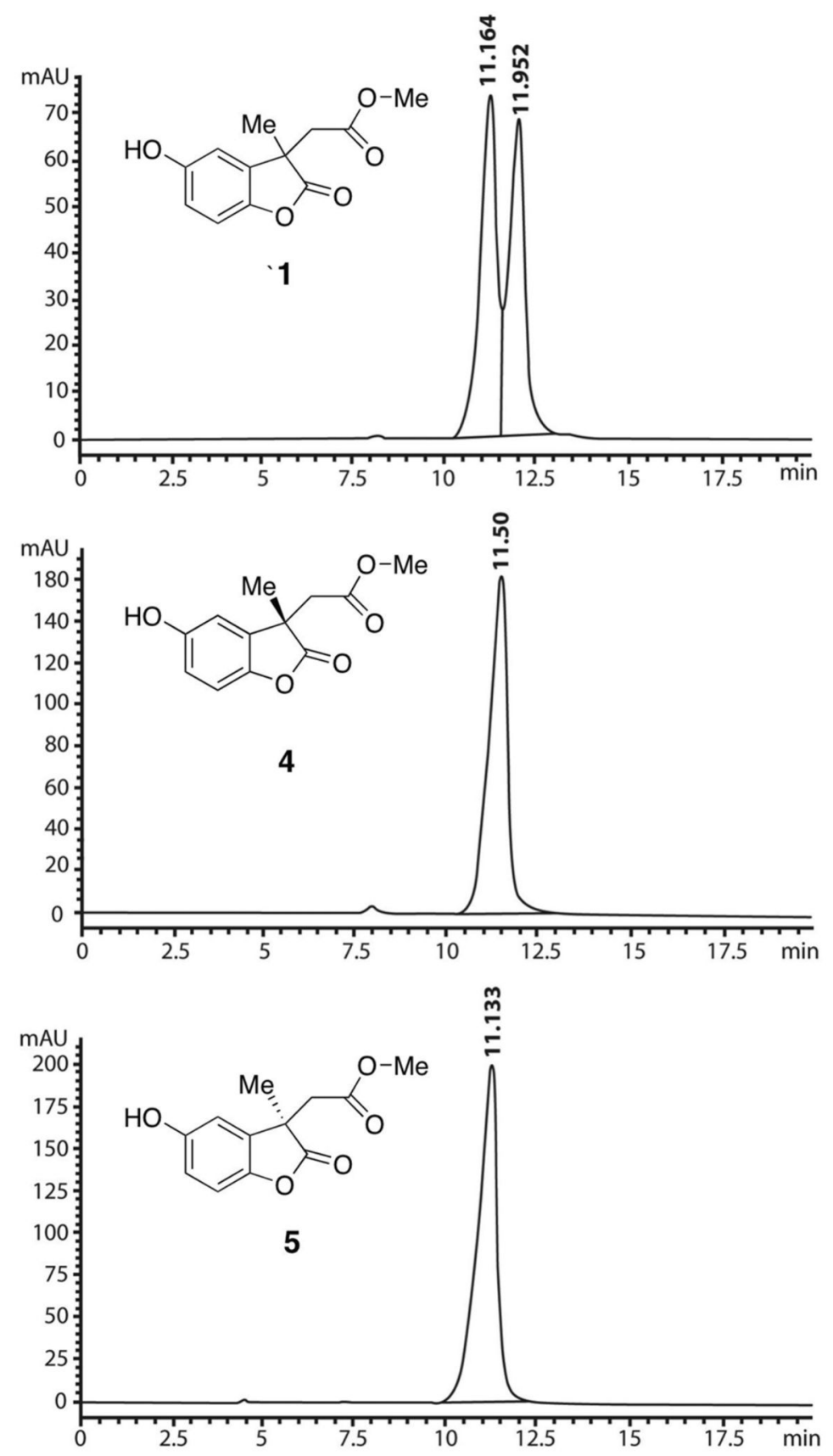

Figure 2.

Chiral HPLC analysisa of compounds 1, 4 and $\mathbf{5}$

a Instrument: HP1100; column: ChiraDex $5 \mu \mathrm{m}$; Flow-rate: $0.5 \mathrm{ml} / \mathrm{min}$; Detection: UV 254 nm; Elutent: $\mathrm{MeOH} / \mathrm{H}_{2} \mathrm{O} 45 / 55$; Temperature: r.t. (Retention times, 1: 11.164 and 11.952 min; 4: $11.50 \mathrm{~min} ; 5: 11.133 \mathrm{~min})$. 


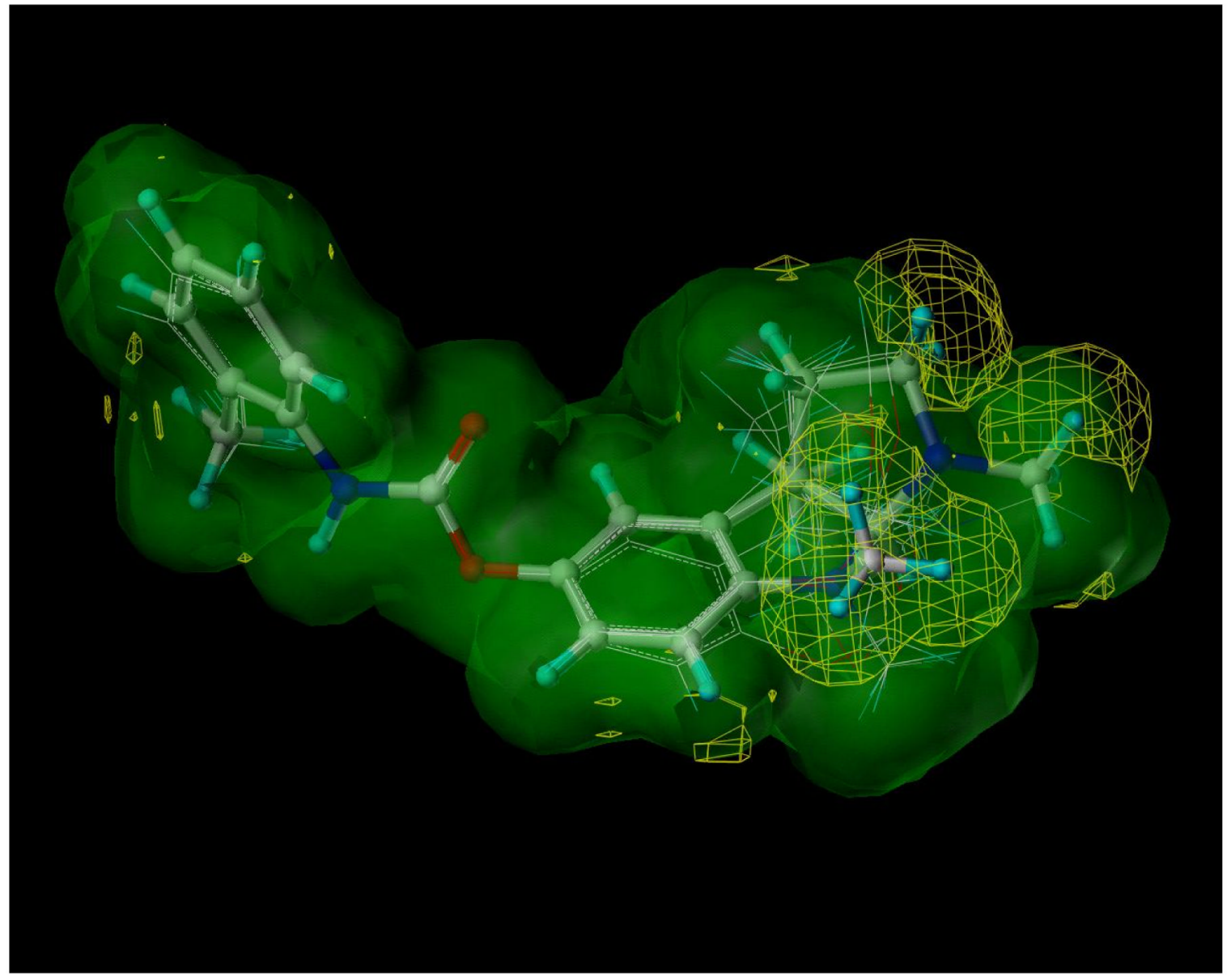

Figure 3.

The union of molecular volume maps for the four active, $S$-configuration compounds $9 \mathbf{a}$, 12a, 17a, 22a (green area) provide the enzyme-excluded volume. The molecular volume map of compound $\mathbf{1 7} \mathbf{b}$ minus the enzyme-excluded volume is the estimate extra volume of $\mathbf{1 7} \mathbf{b}$ (yellow meshed area) 


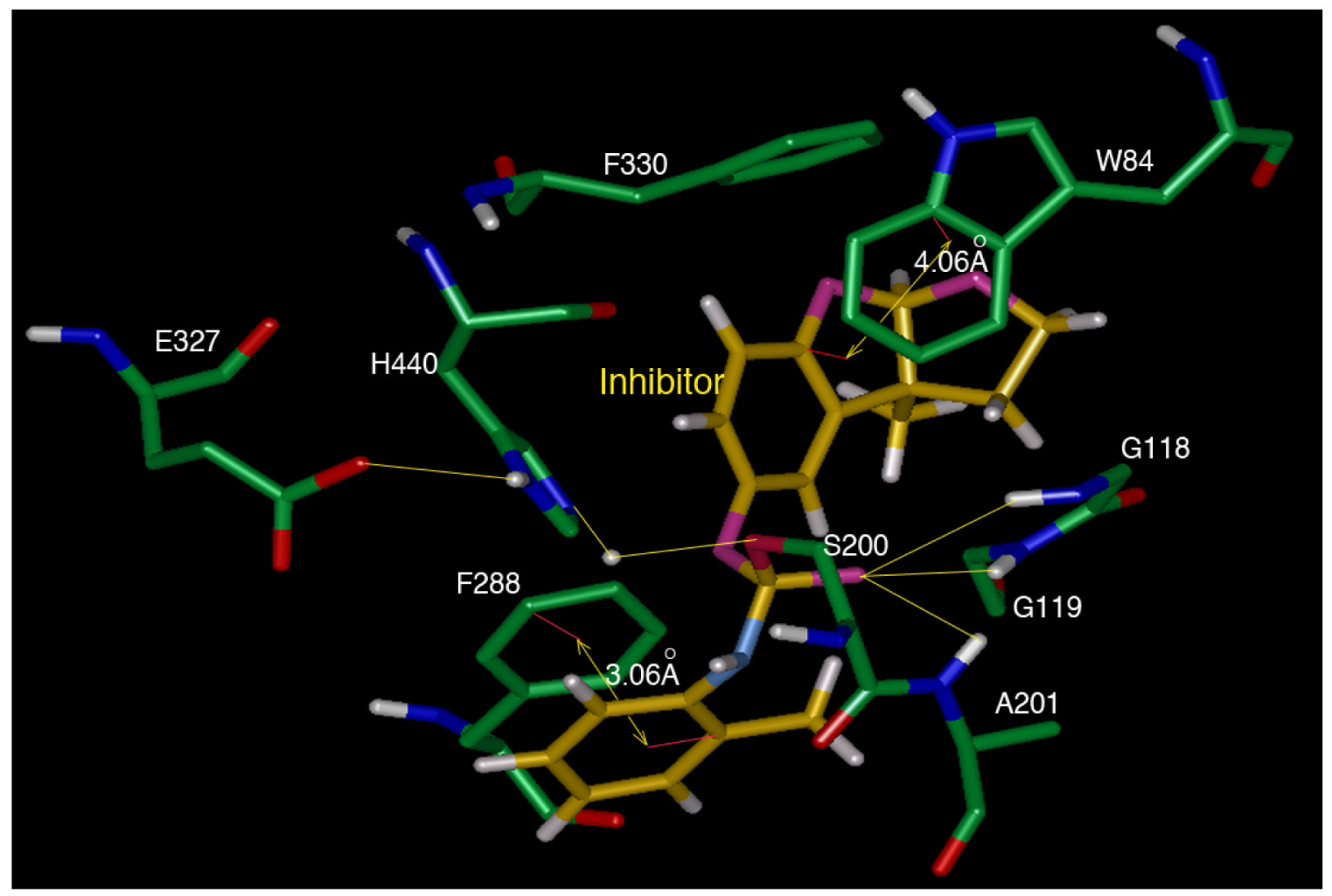

Figure 4.

Close-up of compound $9 \mathbf{a}-T c \mathrm{AChE}$ complex showing its covalent bonding with $\mathrm{Ser}_{200}$. The yellow lines denote hydrogen bond to the residues in the oxyanion hole, i.e. $\mathrm{Gly}_{118}, \mathrm{Gly}_{119}$, and $\mathrm{Ala}_{201}$, and in the catalytic triad, $\mathrm{Ser}_{200}$, His 440 , and $\mathrm{Glu}_{327}$. 
<smiles>[R]NC(=O)Oc1ccc2c(c1)[C@@]1(C)CCN([R7])C1N2C</smiles>

26<smiles></smiles><smiles>[R]CC(C)c1ccc(C)cc1</smiles>

27

$\mathrm{R}_{1}=-\mathrm{CH}_{3}$<smiles>[R]=C1C=CC=C(COc2ccc(C)cc2)C1</smiles>

Figure 5. 
<smiles>COc1cc2c(cc1OC)C(=O)C(CC1CCN(Cc3ccccc3)CC1)C2</smiles><smiles>C/C=C(/N)Cc1ccc(=O)[nH]c1CC(C)C</smiles>

Huperzine A<smiles>CCN(C)C(=O)Oc1cccc([C@@H](C)N(C)C)c1</smiles>

Rivastigmine (Exelon)<smiles>COc1ccc2c3c1O[C@H]1C[C@@H](O)C=CC31CCN(C)C2</smiles>

Galantamine (Reminyl)<smiles>CN1CC[C@]2(C)c3cc(OC(=O)Nc4ccccc4)ccc3N(C)C12</smiles>

(-)-Phenserine<smiles>Nc1c2c(nc3ccccc13)CCCC2</smiles>

Tacrine (Cognex)<smiles>CCCCCCCNC(=O)Oc1ccc2c(c1)[C@]1(C)CCN(C)C1N2C</smiles><smiles>CC(C)c1ccc(CCC(=O)CCc2ccc(C(C)C)cc2)cc1</smiles>

BW284c51<smiles>CCCNP(=O)(NCCC)OP(=O)(NCCC)NCCC</smiles>

iso-OMPA

Figure 6.

Chemical structures of clinically relevant cholinesterase inhibitors (Table 2) 


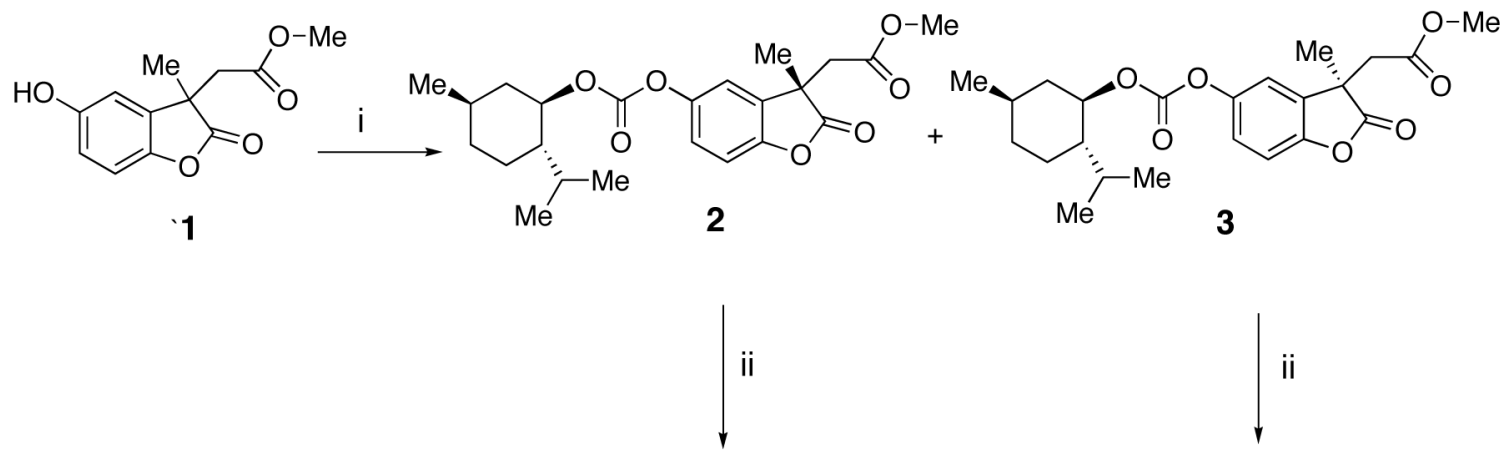

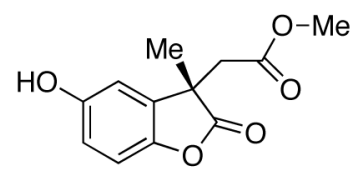

4

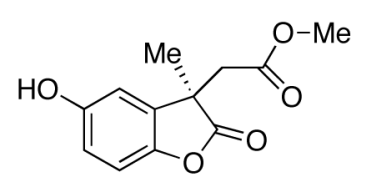

5

Scheme 1.

i) a, (-)-Menthy chloroformate, $\mathrm{Et}_{3} \mathrm{~N}$, benzen, $\mathrm{N}_{2}$, r.t., $1.5 \mathrm{hrs}$; b, recrystallized several times in hexane, then in ethanol. ii) a, $\mathrm{NaOH}, \mathrm{MeOH}$, r.t., 1.5 hrs; b, r.t. $1 \mathrm{~N} \mathrm{HCl}$ 

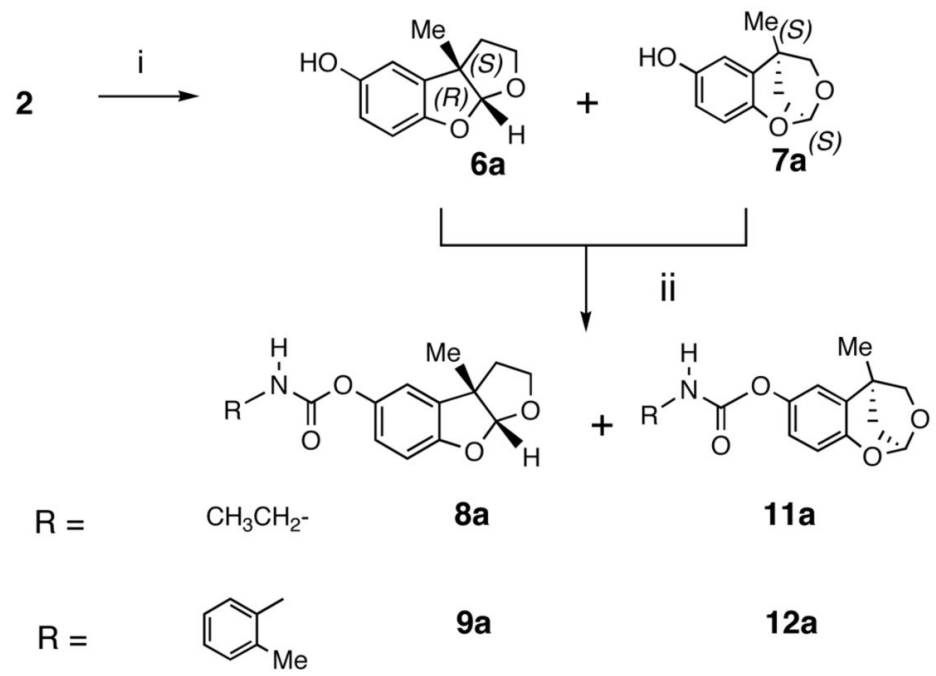

$9 a$

$12 a$<smiles>Cc1ccc(C(C)C)cc1</smiles>

$10 a$

$13 a$
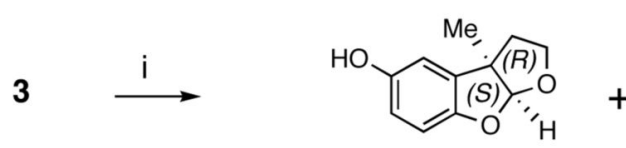

6b

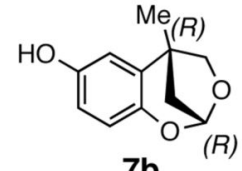

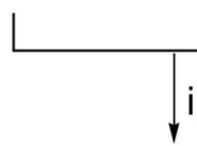

$7 b$<smiles>[R]NC(=O)Oc1ccc2c(c1)C1(C)CCO[C@H]1O2</smiles><smiles>[Y]NC(=O)Oc1ccc2c(c1)[C@]1(C)CO[C@@H](C1)O2</smiles>

$\mathrm{R}=$

$\mathrm{CH}_{3} \mathrm{CH}_{2}-$

$8 b$

11b

$\mathrm{R}=$<smiles>Cc1ccccc1C</smiles>

$9 b$

$12 b$<smiles>[CH2-]C(C)c1ccc(C)cc1</smiles>

$10 \mathrm{~b}$

13b

Scheme 2.

i) a. $\mathrm{LAH} / \mathrm{Et}_{2} \mathrm{O}$, r.t., $1 \mathrm{hr}$; b. $1 \mathrm{M} \mathrm{HCl}$ in $\mathrm{Et}_{2} \mathrm{O}$, r.t., 0.5 hr. ii) $\mathrm{Na}$, RNCO/Et2O, r.t., $0.5-1.0$ hr. 

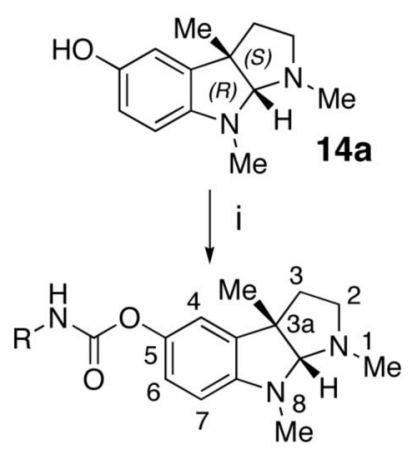

$$
\begin{aligned}
& \mathrm{R}=\mathrm{CH}_{3}^{-} \\
& \mathrm{R}=\mathrm{CH}_{3} \mathrm{CH}_{2^{-}}
\end{aligned}
$$

$15 a$

$16 a$

$17 a$

$18 a$

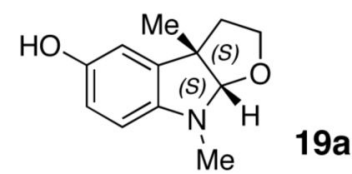<smiles>[R]N1c2ccc(OC(=O)NP)cc2[C@@]2(C)CCO[C@H]1N2C</smiles>

$\mathrm{R}=\mathrm{CH}_{3}-$

20a

$\mathrm{R}=\mathrm{CH}_{3} \mathrm{CH}_{2}^{-}$

$21 a$

$R=\overbrace{M e}$

$22 a$

$23 a$
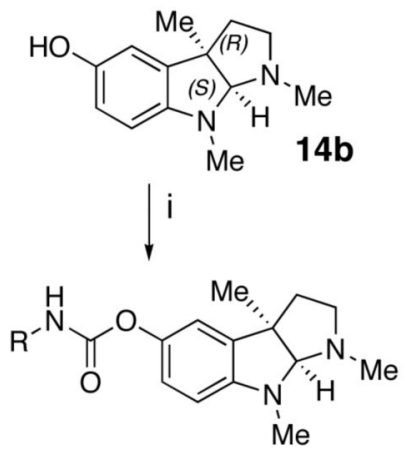

15b

$17 b$

$18 b$<smiles>CN1c2ccc(O)cc2[C@@]2(C)CCO[C@H]1N2C</smiles><smiles>[R]NC(=O)Oc1ccc2c(c1)[C@@]1(C)CCO[C@H]1N2C</smiles>

$20 b$

22b

23b

Scheme 3.

i) $\mathrm{Na}, \mathrm{RNCO} / \mathrm{Et}_{2} \mathrm{O}$, r.t. 

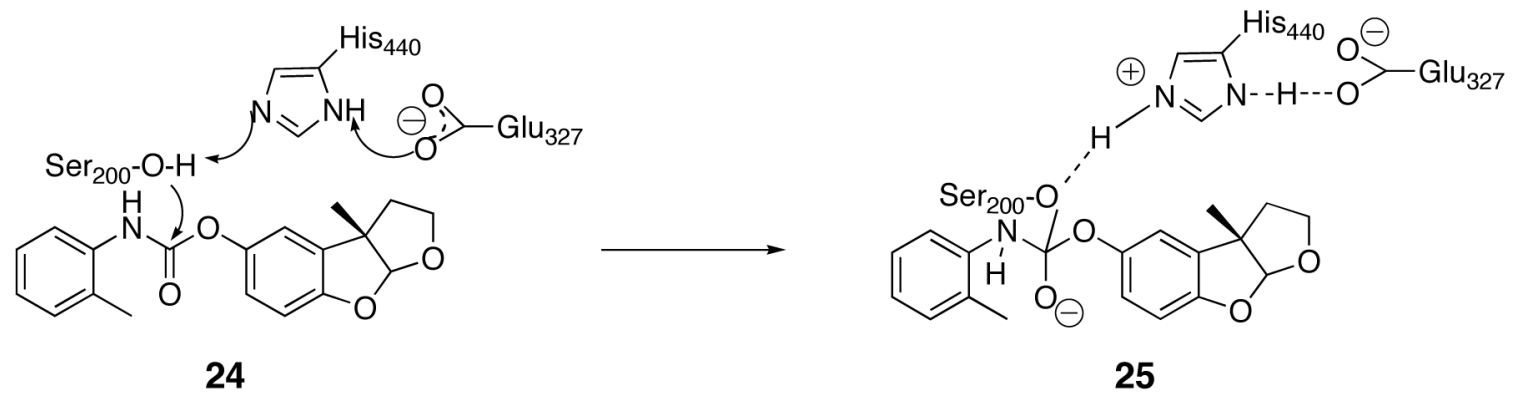

Scheme 4. 
Luo et al.

Page 28

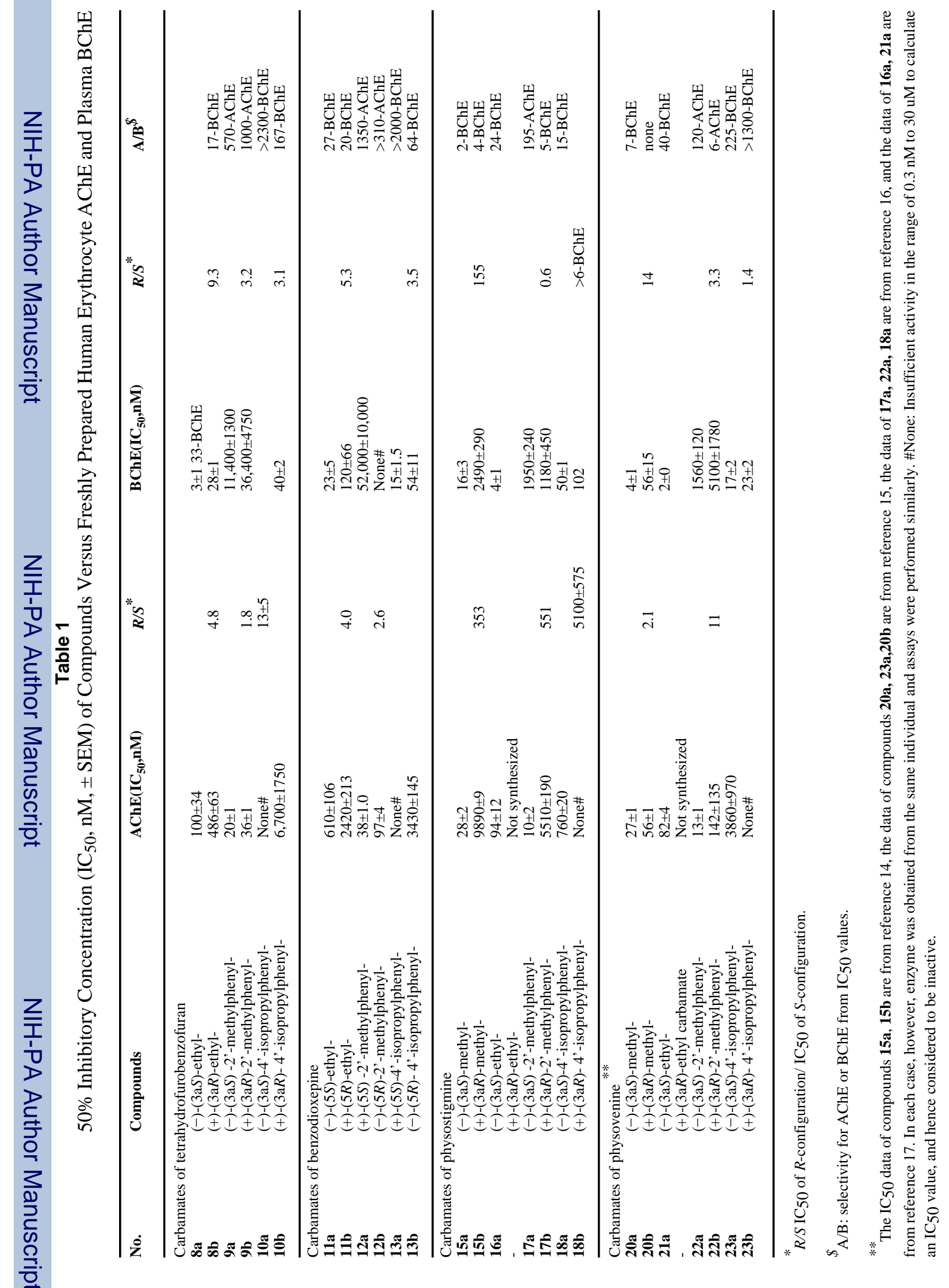

J Med Chem. Author manuscript; available in PMC 2008 December 29. 
Table 2

Comparison of the $\mathrm{IC}_{50}$ Values $( \pm \mathrm{SEM})$ of Approved ChEIs of Clinical Interest Versus Freshly Prepared Human Erythrocyte AChE and Plasma BChE (Figure 6)

\begin{tabular}{lccc}
\hline & \multicolumn{2}{c}{ IC $_{\mathbf{5 0}}$ Value ${ }^{*}(\mathbf{n M})$} & \\
\cline { 2 - 3 } Compound & AChE & BChE & Selectivity \\
\hline Tacrine & $190 \pm 40$ & $47 \pm 10$ & $4-\mathrm{BChE}$ \\
Donepezil & $22 \pm 8$ & $4150 \pm 1700$ & $188-\mathrm{AChE}$ \\
Rivastigmine & $4150 \pm 160$ & $37 \pm 5$ & $122-\mathrm{BChE}$ \\
Galanthamine & $800 \pm 60$ & $7300 \pm 830$ & $9-\mathrm{AChE}$ \\
$(-)$-Phenserine & $22 \pm 1.4$ & $1560 \pm 45$ & $70-\mathrm{AChE}$ \\
(-)-(3aS)-phenylcarbamate of physostigmine & $22 \pm 2$ & $5.0 \pm 0.1$ & $4-\mathrm{BChE}$ \\
Heptylstigmine & & & $>212-\mathrm{AChE}$ \\
(-)-(3aS)-heptylcarbamate of physostigmine & $47 \pm 22$ & $>10,000$ & $2660-\mathrm{AChE}$ \\
Huperzine A & $18 \pm 8$ & 98,000 & $35-\mathrm{BChE}$ \\
BW284c51 & 340,000 & $980 \pm 550$ & \\
Iso-OMPA & & & \\
\hline
\end{tabular}

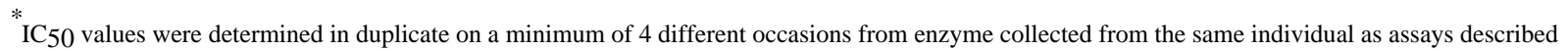
for Table 1.

${ }^{\#}$ BW classical selective inhibitors of $\mathrm{AChE}$ and $\mathrm{BChE}$, respectively 


\section{Table 3}

Estimate Extra Volume* and the Ratio of Anticholinesterase Activity $R / S$

\begin{tabular}{|c|c|c|c|}
\hline No. & Compounds & $\begin{array}{c}\text { Estimate Extra Volume } \\
\left(\AA^{\left.\mathbf{3}^{3}\right)}\right.\end{array}$ & $R / S(\mathrm{AChE})$ \\
\hline $9 b$ & $\begin{array}{l}\text { Tetrahydrofurobenzofuran series } \\
(+)-(3 \mathrm{a} R)-2^{\prime} \text {-methylphenylcarbamate }\end{array}$ & 7.1 & 1.8 \\
\hline $12 b$ & $\begin{array}{l}\text { Dihydrobenzodioxepine series } \\
(-)-(5 R)-2 \text { '-methylphenylcarbamate }\end{array}$ & 19.9 & 2.6 \\
\hline $17 b$ & $\begin{array}{l}\text { Physostigmine series } \\
(+)-(3 \mathrm{a} R)-2^{\prime} \text {-methylphenylcarbamate }\end{array}$ & 24.8 & 551 \\
\hline $22 b$ & $\begin{array}{l}\text { Physovenine series } \\
(+)-(3 \mathrm{a} R)-2 \text { '-methylphenylcarbamate }\end{array}$ & 19.4 & 11 \\
\hline
\end{tabular}

